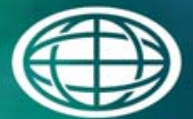

Savannah River

National Laboratory "m

OPERATED BY SAVANNAH RIVER NUCLEAR SOLUTIONS

\title{
Tank 12H Acidic Chemical Cleaning Sample Analysis and Material Balance
}

\author{
C. J. Martino \\ S. H. Reboul \\ B. J. Wiersma \\ C. J. Coleman
}

November 2013

SRNL-STI-2013-00459, Revision 0 
SRNL-STI-2013-00459

Revision 0

\section{DISCLAIMER}

This work was prepared under an agreement with and funded by the U.S. Government. Neither the U.S. Government or its employees, nor any of its contractors, subcontractors or their employees, makes any express or implied:

1. warranty or assumes any legal liability for the accuracy, completeness, or for the use or results of such use of any information, product, or process disclosed; or

2. representation that such use or results of such use would not infringe privately owned rights; or

3. endorsement or recommendation of any specifically identified commercial product, process, or service.

Any views and opinions of authors expressed in this work do not necessarily state or reflect those of the United States Government, or its contractors, or subcontractors.

\section{Printed in the United States of America \\ Prepared for U.S. Department of Energy}


Keywords: Oxalic Acid, Sludge

Dissolution, Heel Removal, Waste Tanks

Retention: Permanent

\title{
Tank 12H Chemical Cleaning Sample Analysis and Material Balance
}

\author{
C. J. Martino \\ S. H. Reboul \\ B. J. Wiersma \\ C. J. Coleman
}

November 2013

Prepared for the U.S. Department of Energy under 


\section{REVIEWS AND APPROVALS}

\section{AUTHORS:}

C. J. Martino, Advanced Characterization and Processing Date

S. H. Reboul, Advanced Characterization and Processing Date

B. J. Wiersma, Materials Science and Engineering Date

\begin{tabular}{ll}
\hline C. J. Coleman, Analytical Development & Date
\end{tabular}

TECHNICAL REVIEW:

M. S. Hay, Advanced Characterization and Processing, Review per E7 2.60 Date

APPROVAL:

F. M. Pennebaker, Manager

Date

Advanced Characterization and Processing

S. L. Marra, Manager

Date

Environmental \& Chemical Process Technology Research Programs

J. R. Vitali, Manager

Date

SRR Flowsheet Development \& Facility Integration 


\section{EXECUTIVE SUMMARY}

A process of Bulk Oxalic Acid (BOA) chemical cleaning was performed for Tank $12 \mathrm{H}$ during June and July of 2013 to remove all or a portion of the approximately 4400 gallon sludge heel. Three strikes of oxalic acid (nominally $4 \mathrm{wt} \%$ or $2 \mathrm{wt} \%$ ) were used at $55^{\circ} \mathrm{C}$ and tank volumes of 96- to 140-thousand gallons. This report details the sample analysis of a scrape sample taken prior to BOA cleaning and dip samples taken during BOA cleaning. It also documents a rudimentary material balance for the Tank $12 \mathrm{H}$ cleaning results.

The following are the key observations for Tank 12H Scrape Sample HTF-12-12-107 taken prior to BOA cleaning of the tank heel:

- Iron and manganese were the primary components, followed by aluminum, mercury, uranium, sodium, silicon, nickel and thorium.

- Compared with previous Tank $12 \mathrm{H}$ sludge samples, the scrape sample had a relatively low aluminum:iron ratio of approximately 1:3.

- In terms of activity on a wet basis, the primary radionuclides are strontium-90 at $8.7 \times 10^{3} \mu \mathrm{Ci} / \mathrm{g}$ and cesium-137 at $1.7 \times 10^{2} \mu \mathrm{Ci} / \mathrm{g}$.

The following are the key observations for the Tank 12H Supernate Samples taken during BOA cleaning. One sample was removed at the end of each BOA cleaning strike. Additionally, two intermediate samples were analyzed for the first BOA cleaning strike.

- The samples contained insoluble solids with a measured range of $0.00 \mathrm{wt} \%$ to $0.34 \mathrm{wt} \%$. Chemical and radiological analyses were performed on solids-free filtrate.

- $\mathrm{Fe}^{2+}$ content was $2 \%$ or less of the total iron (ranging from $0.9 \%$ to $1.9 \%$ ) for each strike.

- Based on the soluble ferric species concentrations at the end of each of the three BOA cleaning strikes, ferric ion reduction was the primary cathodic reaction during chemical cleaning and not hydrogen gas generation. Controlling the exposure time of the carbon steel to the oxalic acid appears to have been effective in mitigating evolution of the flammable gas.

- The major components in the supernate were iron, sodium, manganese, uranium, and aluminum.

- $\mathrm{Pu}-238$ was present in the supernate at up to $0.6 \mu \mathrm{Ci} / \mathrm{mL}$ (at the end of the first strike).

- I-129 and Am-241 were below the method detection limits.

The following are the key observations for the material balance constructed from the Tank $12 \mathrm{H}$ sample data:

- A material balance based only on an initial sample of tank heel solids from a single location and samples of solids-free supernatant liquid from the end of each strike requires multiple assumptions to be made that in-turn limit the applicability of the material balance for determining the amount and composition of the solids remaining in the tank.

- Components that had high, near-complete removal $(>85 \%)$ include sodium, potassium, and phosphorus.

- Components that had moderate, significant partial removal (40\% to $70 \%)$ include uranium, gross beta/gamma, chromium, iron, magnesium, calcium, zirconium, and silicon.

- Components that had low to borderline moderate, minor removal (15\% to $35 \%$ ) include plutonium, aluminum, manganese, copper, barium, and lithium.

- Components that had low, negligible removal $(<6 \%)$ include mercury, thorium, and nickel. 


\section{TABLE OF CONTENTS}

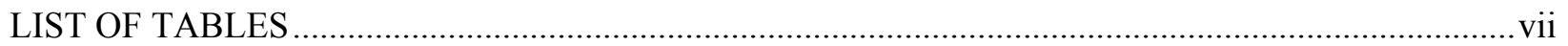

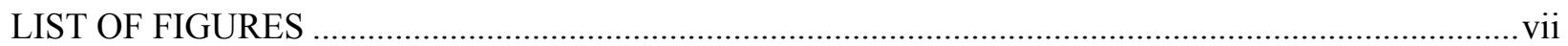

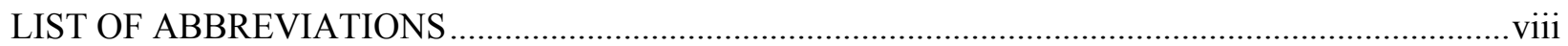

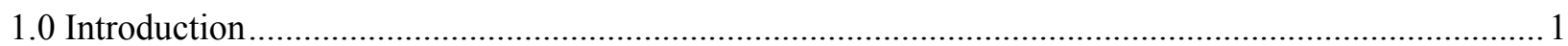

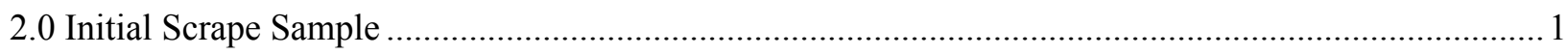

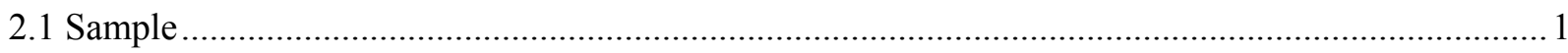

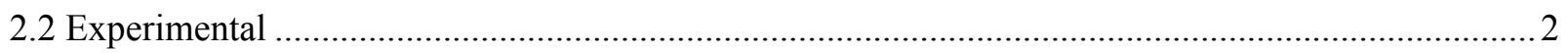

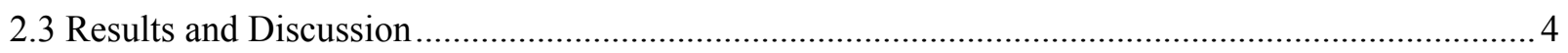

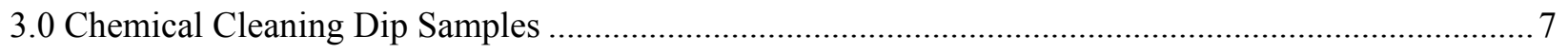

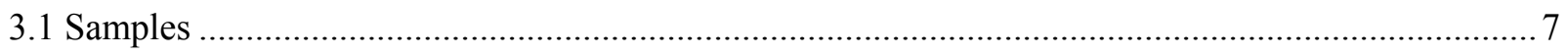

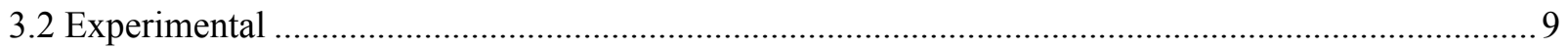

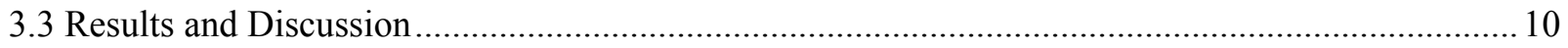

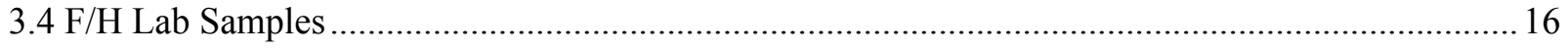

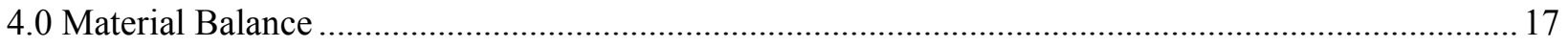

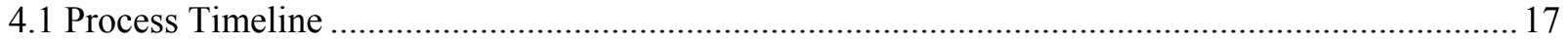

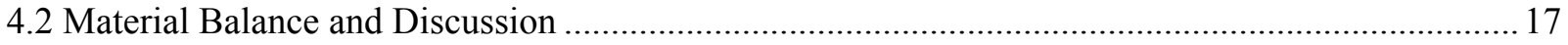

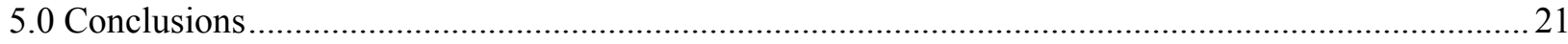

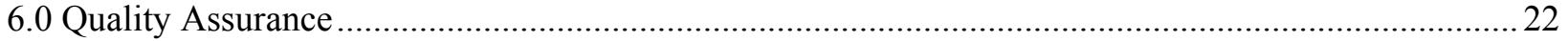

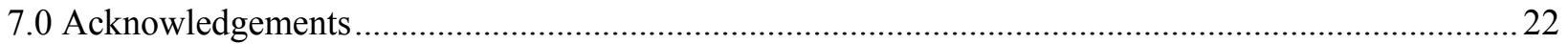

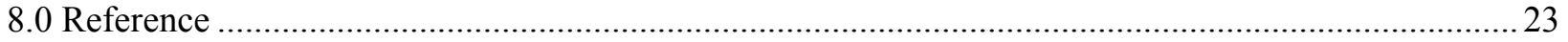




\section{LIST OF TABLES}

Table 2-1. The requested analytes / units; and the projected measurement methods to reach the requested level of detection 3

Table 2-2: Elemental Analysis of Tank 12H Scrape Sample HTF-12-12-107 (wt \%, wet basis)..............5

Table 2-3: Radionuclide Analysis of Tank 12H Scrape Sample HTF-12-12-107 (wet basis)................... 6

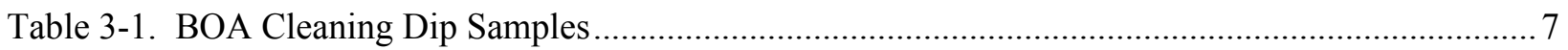

Table 3-2. Requested BOA cleaning dip sample SRNL analyses ...................................................... 9

Table 3-3. Solids and Density Measurements for BOA Cleaning Dip Samples ...................................... 10

Table 3-4. Iron Oxidation State Results for Soluble Portion of BOA Cleaning Samples......................... 11

Table 3-5. ICP-ES Analysis of Soluble Portion of Tank 12H BOA Cleaning Dip Samples (mg/L)......... 13

Table 3-6. ICP-MS Analysis for Fission Products in Soluble Portion of Tank 12H BOA Cleaning Dip

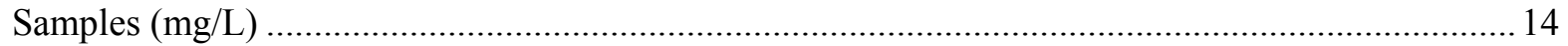

Table 3-7. ICP-MS Analysis for Actinides in Soluble Portion of Tank 12H BOA Cleaning Dip Samples

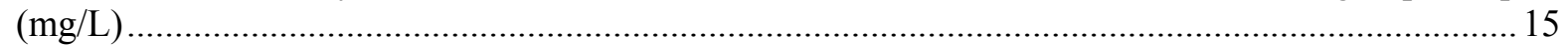

Table 3-8. Radionuclides Analyzed in Tank 12H BOA Cleaning Dip Samples ( $\mu \mathrm{Ci} / \mathrm{mL})$..................... 16

Table 4-1. Material Balance for Major Chemical Components ............................................................ 19

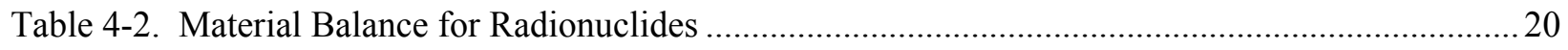

Table 4-3. Material Balanced based on F/H Lab Dip Sample Characterization .....................................20

Table 4-4. Comparison of Calculated Removal Percentages During the Current Tank 12H BOA Cleaning

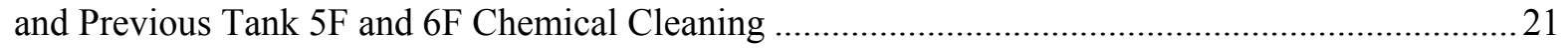

\section{LIST OF FIGURES}

Figure 2-1. Tank 12H scrape sample HTF-12-12-107 received in a PVC container (left) and transferred into a $125 \mathrm{~mL}$ glass jar (right). .............................................................................................

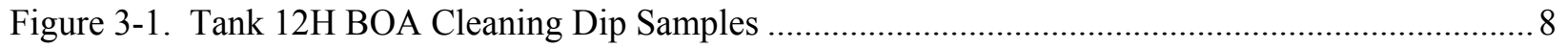




\section{LIST OF ABBREVIATIONS}

$\begin{array}{ll}\text { BOA } & \text { Bulk Oxalic Acid } \\ \text { C. I. } & \text { Confidence Interval } \\ \text { CVAA } & \text { Cold Vapor Atomic Absorption } \\ \text { EA } & \text { Environmental Assessment } \\ \text { HLW } & \text { High-Level Waste } \\ \text { IC } & \text { Ion Chromatography } \\ \text { ICP-ES } & \text { Inductively Coupled Plasma - Emission Spectroscopy } \\ \text { ICP-MS } & \text { Inductively Coupled Plasma - Mass Spectroscopy } \\ \text { LSC } & \text { Liquid Scintillation Counting } \\ \text { n } & \text { Number of replicate measurements } \\ \text { N/A } & \text { Not Applicable } \\ \text { OA } & \text { Oxalic Acid } \\ \text { PuTTA } & \text { Pu separation by Thenoyltrifluoroacetone } \\ \text { RSD } & \text { Relative Standard Deviation } \\ \text { SRNL } & \text { Savannah River National Laboratory } \\ \text { SRR } & \text { Savannah River Remediation } \\ \text { SRS } & \text { Savannah River Site } \\ \text { TIC/TOC } & \text { Total Inorganic Carbon/Total Organic Carbon } \\ \text { TT\&QAP } & \text { Task Technical and Quality Assurance Plan } \\ \text { TTR } & \text { Technical Task Request }\end{array}$


SRNL-STI-2013-00459

Revision 0

\subsection{Introduction}

In support of Savannah River Site (SRS) tank closure efforts, Savannah River Remediation (SRR), the tank farms operations contractor, implemented a bulk oxalic acid (BOA) cleaning process in High Level Waste (HLW) Tank 12H. After bulk waste removal efforts and subsequent aluminum dissolution, sludge washing, and mechanical heel removal, Tank $12 \mathrm{H}$ had an estimated 4400 gallons of sludge remaining. ${ }^{1}$ Prior to initiating BOA cleaning, an initial scrape sample of the Tank 12H sludge heel was collected and then sent to the Savannah River National Laboratory (SRNL) for analysis of various chemical and radioactive components and physical properties. During BOA cleaning, dip samples were taken at the end of each strike and analyzed for iron oxidation state and other chemical and radioactive components. Additional dip samples were taken at intermediate points in the BOA process.

This work is outlined and authorized in a Technical Task Request ${ }^{2}$ and a Task Technical and Quality Assurance Plan. ${ }^{3}$ Details of the BOA cleaning performed for Tank $12 \mathrm{H}$ during June and July of 2013 are compiled in a Completion Report. ${ }^{4}$

\subsection{Initial Scrape Sample}

\subsection{Sample}

On November 2, 2012, SRR sampled the accessible sludge at the bottom of Tank 12H. The sample (HTF-12-12-107) was delivered to SRNL on November 5 and placed into the Shielded Cells. Figure 2-1 contains photographs of the sample HTF-12-12-107 taken during sample receipt and opening. The sample consisted of brown solids that were not free-flowing and a small amount of free-flowing slurry. After removal of material from the sampler and separation of solids from the free-flowing portion of sample, HTF-12-12-107 was determined to contain 27.553 grams of wet solids and 0.868 grams of solids-free liquid. Analyses that are reported on a "wet solids" basis were performed on the 27.553 grams of wet solids after the removal of 0.868 grams of liquid. 

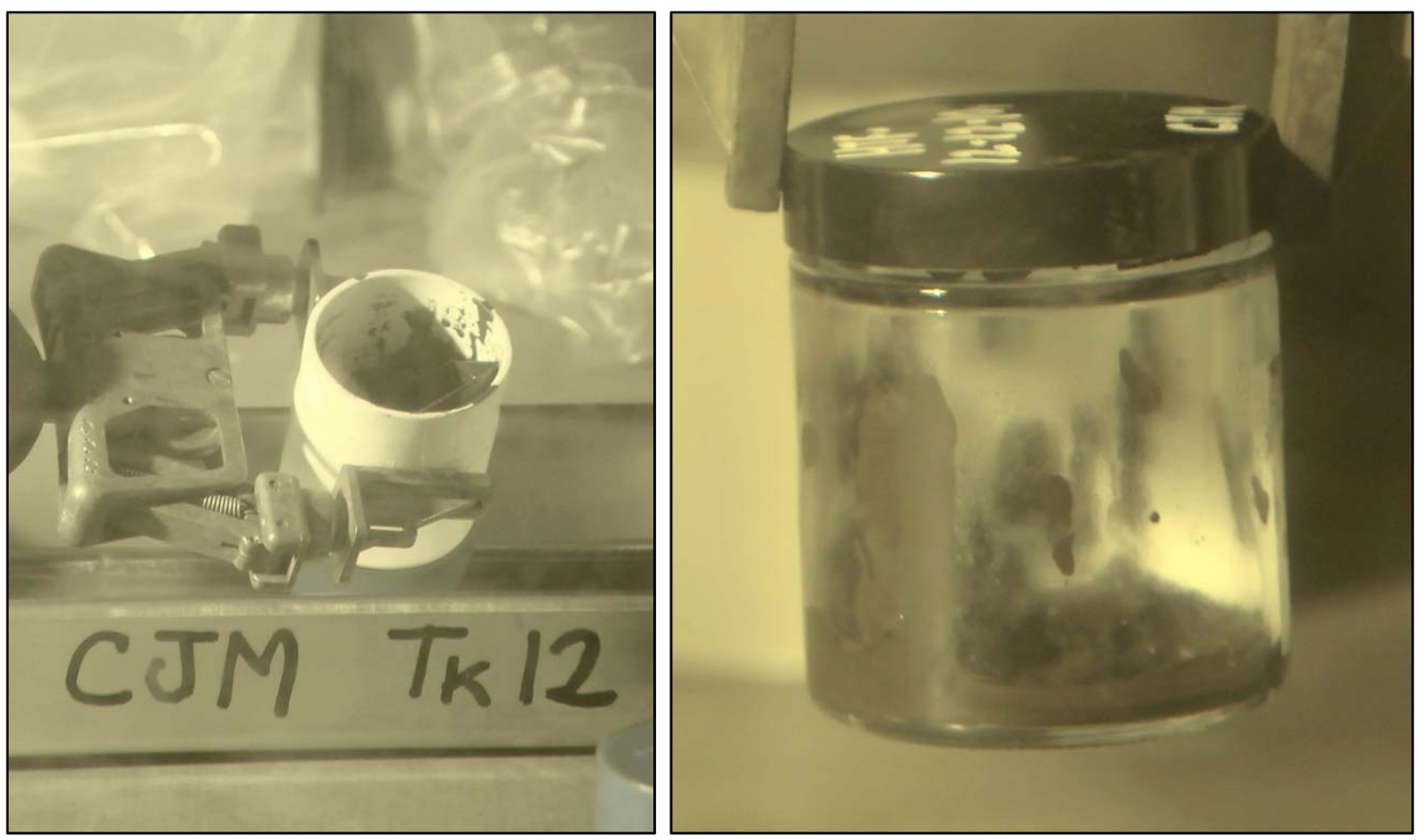

Figure 2-1. Tank 12H scrape sample HTF-12-12-107 received in a PVC container (left) and transferred into a $125 \mathrm{~mL}$ glass jar (right).

\subsection{Experimental}

Table 2-1 outlines the analyses requested for the wet solids portion of sample HTF-12-12-107. Table 2-1 also specifies the requested reporting units, the projected measurement method, and the requested minimum detection limits, where applicable.

There were no apparent large chunks that required crushing in the sample. For homogenization, the wet solids were mixed with a spatula prior to characterization. 
SRNL-STI-2013-00459

Revision 0

Table 2-1. The requested analytes / units; and the projected measurement methods to reach the requested level of detection

\begin{tabular}{|c|c|c|c|}
\hline analyte & units & measurement method & $\begin{array}{c}\text { requested minimum } \\
\text { detection }\end{array}$ \\
\hline density & $\mathrm{g} / \mathrm{mL}$ & solids bulk density & $\mathrm{N} / \mathrm{A}$ \\
\hline total solids & wt $\%$ & gravimetric drying & $\mathrm{N} / \mathrm{A}$ \\
\hline Sr-90 & $\mu \mathrm{Ci} / \mathrm{g}$ and $\mathrm{wt} \%$ & Sr-90 & $1.0 \mathrm{E}-03 \mu \mathrm{Ci} / \mathrm{g}$ \\
\hline Tc-99 & $\mu \mathrm{Ci} / \mathrm{g}$ and $\mathrm{wt} \%$ & Tc-99 & $5.0 \mathrm{E}-03 \mu \mathrm{Ci} / \mathrm{g}$ \\
\hline I-129 & $\mu \mathrm{Ci} / \mathrm{g}$ and $\mathrm{wt} \%$ & I-129 & $1.0 \mathrm{E}-04 \mu \mathrm{Ci} / \mathrm{g}$ \\
\hline Cs-137 & $\mu \mathrm{Ci} / \mathrm{g}$ and $\mathrm{wt} \%$ & gamma counting of $\mathrm{Ba}-137 \mathrm{~m}$ & $1.0 \mathrm{E}-03 \mu \mathrm{Ci} / \mathrm{g}$ \\
\hline Np-237, U-238 & $\mu \mathrm{Ci} / \mathrm{g}$ and $\mathrm{wt} \%$ & ICP-MS & $1.0 \mathrm{E}-03 \mu \mathrm{Ci} / \mathrm{g}$ \\
\hline $\mathrm{Pu}-238, \mathrm{Pu}-239 / 240$ & $\mu \mathrm{Ci} / \mathrm{g}$ and $\mathrm{wt} \%$ & PuTTA & $1.0 \mathrm{E}-03 \mu \mathrm{Ci} / \mathrm{g}$ \\
\hline Am-241 & $\mu \mathrm{Ci} / \mathrm{g}$ and $\mathrm{wt} \%$ & Cs-removed gamma & $1.0 \mathrm{E}-03 \mu \mathrm{Ci} / \mathrm{g}$ \\
\hline metals & wt $\%$ & ICP-ES & N/A \\
\hline $\mathrm{Hg}$ & wt $\%$ & CVAA & N/A \\
\hline $\mathrm{NO}_{3}^{-}, \mathrm{NO}_{2}^{-}, \mathrm{C}_{2} \mathrm{O}_{4}^{2-}$ & wt $\%$ & IC anions & $\mathrm{N} / \mathrm{A}$ \\
\hline
\end{tabular}

There is not a routine method used to determine the bulk density of non-flowing wet solids. The Tank $12 \mathrm{H}$ scrape sample is too thick to use the method used for sludge slurries without diluting the material and too wet to use the method used for closure samples without first drying the material. The bulk density was measured by water displacement. An approximately $1 \mathrm{~mL}$ container of known volume was filled with a portion of wet solids and the remaining portion with water. For saturated wet solid cakes, the density from this displacement method will give values appropriate for conversion between the analytical results in this report (on a wet mass basis) and the in-tank sludge heel quantity (on a volume basis).

Total solids content was determined by drying nominally 0.35 gram portions of wet solids to a constant weight at $115 \pm 5{ }^{\circ} \mathrm{C}$. This measurement was performed in triplicate in conjunction with peroxide fusion sample digestion preparations.

Two main preparation methods were performed in triplicate on the Tank $12 \mathrm{H}$ scrape sample wet solids. Peroxide fusion digestion was used as the preparation for plutonium by the PuTTA method and metals by Inductively Coupled Plasma - Emission Spectroscopy (ICP-ES). Aqua regia dissolution was used as the preparation for the majority of the other analyses, including Inductively Coupled Plasma - Mass Spectroscopy (ICP-MS), ICP-ES, Cold Vapor Atomic Absorption (CVAA), gamma counting $(\gamma)$, Cs-removed gamma counting (Cs-r $\gamma$ ), and Sr-90 analysis. To achieve the requested detection limits for sample material with high overall beta/gamma activity, the radiochemical preparation methods for Tc-99 and I-129 had to be performed in the Shielded Cells. 
From sample handling tasks, two types of sample liquids were available for analysis. The first liquid was the small amount of separable free liquid that was received with the sample. The second liquid resulted from leaching the wet solids with water for several days. Both liquids were filtered and diluted to provide the required volume for analysis. The analysis included Ion Chromatography (IC) for anions, acid titration for free hydroxide, Total Inorganic Carbon/Total Organic Carbon (TIC/TOC) analysis, and $\mathrm{pH}$ measurement.

\subsection{Results and Discussion}

The weight percentage of total solids was measured during sample drying required for the peroxide fusion digestion. Three total solids measurements were performed, averaging $49.7 \mathrm{wt} \%$ with a standard deviation of $2.6 \mathrm{wt} \%$. Three determinations of the density were made by the method described in the previous section. The approximate bulk density of the saturated material averaged $1.65 \mathrm{~g} / \mathrm{mL}$ with a standard deviation of $0.04 \mathrm{~g} / \mathrm{mL}$.

Table 2-2 and Table 2-3 contain the analysis results for the elemental and radionuclide components, respectively, for the wet solids from Tank 12H scrape sample HTF-12-12-107. These results contain the sludge interstitial liquid and are reported on a wet basis. Results are preceded by "<" when the analyte is less than the lower limits of quantification. The individual determinations of the preparations and measurements are reported, along with the "combined/best" result. In cases where the indicators suggested that one preparation method provided better analytical results or that lower limits or quantification were achieved, the combined/best result only includes results from the preferred preparation method. The combined/best results are reported as average values and the corresponding Relative Standard Deviation (RSD) values. RSD values are not reported when all measurements are less than the lower limits of quantification. The greyed out values in Table 2-2 and Table 2-3 are not used in the calculation of the combined/best values.

Table 2-2 results are exclusively by ICP-ES analysis, with the exception of mercury, which was measured by CVAA.

Table 2-2 shows that iron and manganese are the primary components of the solids, followed by aluminum, mercury, uranium, sodium, silicon, nickel and thorium. The sum of the components is low relative to previous Tank $12 \mathrm{H}$ sludge analyses because this analysis is reported on a wet basis and the material has significant water content. This material has an aluminum:iron ratio of approximately 1:3. The aluminum:iron ratio of HTF-12-12-107 is much lower than that of a composite of Tank $12 \mathrm{H}$ sludge samples taken during sludge retrieval and prior to the in-tank aluminum dissolution campaign. That previous Tank $12 \mathrm{H}$ sludge composite sample had an aluminum:iron ratio of approximately $5.8: 1 .^{5}$

Table 2-3 shows that the primary radionuclides in terms of activity in the wet solid sample are strontium-90 at $8.7 \times 10^{3} \mu \mathrm{Ci} / \mathrm{g}$ and cesium- 137 at $1.7 \times 10^{2} \mu \mathrm{Ci} / \mathrm{g}$. All requested radionuclides were quantified in the Tank $12 \mathrm{H}$ scrape sample. 
Table 2-2: Elemental Analysis of Tank 12H Scrape Sample HTF-12-12-107 (wt \%, wet basis)

\begin{tabular}{|c|c|c|c|c|c|c|c|c|c|}
\hline \multirow{2}{*}{ wt $\%$} & \multicolumn{3}{|c|}{ Aqua Regia Dissolution } & \multicolumn{3}{|c|}{ Peroxide Fusioin Digestion } & \multicolumn{3}{|c|}{ Combined / Best } \\
\hline & average & RSD & $n$ & average & RSD & $n$ & average & RSD & $\mathrm{n}$ \\
\hline $\mathrm{Ag}$ & $1.10 \mathrm{E}-02$ & $3.5 \%$ & 3 & $<9.73 \mathrm{E}-02$ & -- & -- & $1.10 \mathrm{E}-02$ & $3.5 \%$ & 3 \\
\hline $\mathrm{Al}$ & $3.06 \mathrm{E}+00$ & $3.1 \%$ & 3 & $3.36 \mathrm{E}+00$ & $8.9 \%$ & 3 & $3.36 \mathrm{E}+00$ & $8.9 \%$ & 3 \\
\hline $\mathrm{B}$ & $<9.00 \mathrm{E}-03$ & $8.7 \%$ & 3 & $<1.33 \mathrm{E}-01$ & -- & -- & $<9.00 \mathrm{E}-03$ & -- & -- \\
\hline $\mathrm{Ba}$ & $5.09 \mathrm{E}-02$ & $4.2 \%$ & 3 & 4.97E-02 & $2.3 \%$ & 3 & $5.03 \mathrm{E}-02$ & $3.3 \%$ & 6 \\
\hline $\mathrm{Be}$ & $<3.16 \mathrm{E}-04$ & $8.7 \%$ & 3 & $<3.94 \mathrm{E}-04$ & -- & -- & $<3.55 \mathrm{E}-04$ & -- & -- \\
\hline $\mathrm{Ca}$ & $2.95 \mathrm{E}-01$ & $6.0 \%$ & 3 & 4.39E-01 & -- & -- & $2.95 \mathrm{E}-01$ & $6.0 \%$ & 3 \\
\hline $\mathrm{Cd}$ & $2.96 \mathrm{E}-03$ & $10.3 \%$ & 3 & $<8.04 \mathrm{E}-03$ & -- & -- & $2.96 \mathrm{E}-03$ & $10.3 \%$ & 3 \\
\hline $\mathrm{Ce}$ & $5.82 \mathrm{E}-02$ & $3.3 \%$ & 3 & $<4.60 \mathrm{E}-02$ & -- & -- & $5.82 \mathrm{E}-02$ & $3.3 \%$ & 3 \\
\hline Co & $6.72 \mathrm{E}-03$ & $6.5 \%$ & 3 & $<1.04 \mathrm{E}-02$ & -- & -- & $6.72 \mathrm{E}-03$ & $6.5 \%$ & 3 \\
\hline $\mathrm{Cr}$ & $2.89 \mathrm{E}-02$ & $6.5 \%$ & 3 & $3.63 \mathrm{E}-02$ & $9.5 \%$ & 3 & $3.26 \mathrm{E}-02$ & $14.5 \%$ & 6 \\
\hline $\mathrm{Cu}$ & $5.07 \mathrm{E}-02$ & $5.1 \%$ & 3 & $3.18 \mathrm{E}-02$ & $1.3 \%$ & 3 & $4.12 \mathrm{E}-02$ & $25.5 \%$ & 6 \\
\hline $\mathrm{Fe}$ & $9.76 \mathrm{E}+00$ & $2.8 \%$ & 3 & $9.89 \mathrm{E}+00$ & $3.6 \%$ & 3 & $9.83 \mathrm{E}+00$ & $3.0 \%$ & 6 \\
\hline $\mathrm{Gd}$ & $<2.98 \mathrm{E}-02$ & -- & -- & $<7.76 \mathrm{E}-03$ & $3.3 \%$ & 3 & $<7.76 \mathrm{E}-03$ & -- & -- \\
\hline $\mathrm{Hg}$ & $2.33 \mathrm{E}+00$ & $0.9 \%$ & 3 & -- & -- & -- & $2.33 \mathrm{E}+00$ & $0.9 \%$ & 3 \\
\hline K & $4.42 \mathrm{E}-02$ & $3.6 \%$ & 3 & $<2.03 \mathrm{E}-01$ & -- & -- & $4.42 \mathrm{E}-02$ & $3.6 \%$ & 3 \\
\hline $\mathrm{La}$ & $3.15 \mathrm{E}-02$ & $4.1 \%$ & 3 & $2.65 \mathrm{E}-02$ & $4.8 \%$ & 3 & $2.90 \mathrm{E}-02$ & $10.1 \%$ & 6 \\
\hline $\mathrm{Li}$ & $1.17 \mathrm{E}-01$ & $23.9 \%$ & 3 & $1.01 \mathrm{E}-01$ & $29.5 \%$ & 3 & $1.09 \mathrm{E}-01$ & $25.0 \%$ & 6 \\
\hline $\mathrm{Mg}$ & $8.50 \mathrm{E}-02$ & $4.0 \%$ & 3 & $8.10 \mathrm{E}-02$ & $6.2 \%$ & 3 & $8.30 \mathrm{E}-02$ & $5.3 \%$ & 6 \\
\hline $\mathrm{Mn}$ & $7.95 \mathrm{E}+00$ & $7.5 \%$ & 3 & $8.00 \mathrm{E}+00$ & $10.6 \%$ & 3 & $7.98 \mathrm{E}+00$ & $8.3 \%$ & 6 \\
\hline Mo & $<4.45 \mathrm{E}-03$ & -- & -- & $<5.53 \mathrm{E}-02$ & -- & -- & $<4.45 \mathrm{E}-03$ & -- & -- \\
\hline $\mathrm{Na}$ & $1.40 \mathrm{E}+00$ & $4.7 \%$ & 3 & -- & -- & -- & $1.40 \mathrm{E}+00$ & $4.7 \%$ & 3 \\
\hline $\mathrm{Ni}$ & $6.73 \mathrm{E}-01$ & $7.8 \%$ & 3 & $7.66 \mathrm{E}-01$ & $10.2 \%$ & 3 & $7.20 \mathrm{E}-01$ & $10.9 \%$ & 6 \\
\hline $\mathrm{P}$ & $4.68 \mathrm{E}-02$ & $23.1 \%$ & 3 & $<9.36 \mathrm{E}-02$ & -- & -- & $4.68 \mathrm{E}-02$ & $23.1 \%$ & 3 \\
\hline $\mathrm{Pb}$ & $1.20 \mathrm{E}-02$ & $7.2 \%$ & 3 & $<4.60 \mathrm{E}-02$ & -- & -- & $1.20 \mathrm{E}-02$ & $7.2 \%$ & 3 \\
\hline $\mathrm{S}$ & $<2.71 \mathrm{E}-01$ & -- & -- & $<3.37 \mathrm{E}+00$ & -- & -- & $<2.71 \mathrm{E}-01$ & -- & -- \\
\hline $\mathrm{Sb}$ & $<1.56 \mathrm{E}-02$ & -- & -- & $<1.94 \mathrm{E}-01$ & -- & -- & $<1.56 \mathrm{E}-02$ & -- & -- \\
\hline $\mathrm{Si}$ & -- & -- & -- & $8.15 \mathrm{E}-01$ & $2.7 \%$ & 3 & $8.15 \mathrm{E}-01$ & $2.7 \%$ & 3 \\
\hline Sn & $<5.34 \mathrm{E}-02$ & -- & -- & $<6.64 \mathrm{E}-02$ & -- & -- & $<5.34 \mathrm{E}-02$ & -- & -- \\
\hline $\mathrm{Sr}$ & $3.14 \mathrm{E}-02$ & $4.9 \%$ & 3 & $2.98 \mathrm{E}-02$ & $2.9 \%$ & 3 & $3.06 \mathrm{E}-02$ & $4.7 \%$ & 3 \\
\hline Th & $5.93 \mathrm{E}-01$ & $16.0 \%$ & 3 & $6.14 \mathrm{E}-01$ & $23.4 \%$ & 3 & $6.03 \mathrm{E}-01$ & $18.2 \%$ & 6 \\
\hline $\mathrm{Ti}$ & 7.32E-03 & $4.2 \%$ & 3 & $9.41 \mathrm{E}-03$ & $2.6 \%$ & 3 & $9.41 \mathrm{E}-03$ & $2.6 \%$ & 3 \\
\hline $\mathrm{U}$ & $1.88 \mathrm{E}+00$ & $4.4 \%$ & 3 & $1.95 \mathrm{E}+00$ & $5.4 \%$ & 3 & $1.91 \mathrm{E}+00$ & $4.9 \%$ & 6 \\
\hline $\mathrm{V}$ & $<2.85 \mathrm{E}-03$ & -- & -- & $<3.54 \mathrm{E}-03$ & -- & -- & $<2.85 \mathrm{E}-03$ & -- & -- \\
\hline $\mathrm{Zn}$ & $1.67 \mathrm{E}-02$ & $5.0 \%$ & 3 & $2.03 \mathrm{E}-02$ & $3.4 \%$ & 3 & $1.85 \mathrm{E}-02$ & $11.2 \%$ & 6 \\
\hline $\mathrm{Zr}$ & $1.07 \mathrm{E}-01$ & $20.6 \%$ & 3 & -- & -- & -- & $1.07 \mathrm{E}-01$ & $20.6 \%$ & 3 \\
\hline
\end{tabular}


Table 2-3: Radionuclide Analysis of Tank 12H Scrape Sample HTF-12-12-107 (wet basis)

\begin{tabular}{cc|cccc}
\hline analyte & method & avg. $(\mu \mathrm{Ci} / \mathrm{g})$ & avg. $(\mathrm{wt} \%)$ & $\mathrm{RSD}$ & $\mathrm{n}$ \\
\hline $\mathrm{Co}-60$ & Cs-r $\gamma$ & $8.05 \mathrm{E}-02$ & $7.12 \mathrm{E}-09$ & $6.0 \%$ & 3 \\
\hline $\mathrm{Sr}-90$ & $\mathrm{Sr}-90$ & $8.71 \mathrm{E}+03$ & $6.38 \mathrm{E}-03$ & $3.2 \%$ & 3 \\
\hline Tc-99 & Tc-99 & $2.88 \mathrm{E}-03$ & $1.70 \mathrm{E}-05$ & $6.6 \%$ & 3 \\
\hline $\mathrm{I}-129$ & $\mathrm{I}-129$ & $1.36 \mathrm{E}-03$ & $7.72 \mathrm{E}-04$ & $26.1 \%$ & 3 \\
\hline $\mathrm{Cs}-137$ & $\gamma$ & $1.68 \mathrm{E}+02$ & $1.93 \mathrm{E}-04$ & $4.6 \%$ & 3 \\
\hline Eu-152 & Cs-r $\gamma$ & $1.38 \mathrm{E}-01$ & $7.98 \mathrm{E}-08$ & $9.9 \%$ & 3 \\
\hline Eu-154 & Cs-r $\gamma$ & $2.05 \mathrm{E}+00$ & $7.60 \mathrm{E}-07$ & $17.3 \%$ & 3 \\
\hline Th-232 & ICP-MS & $6.01 \mathrm{E}-04$ & $5.48 \mathrm{E}-01$ & $16.5 \%$ & 3 \\
\hline $\mathrm{U}-233$ & ICP-MS & $2.55 \mathrm{E}-02$ & $2.63 \mathrm{E}-04$ & $10.4 \%$ & 3 \\
\hline $\mathrm{U}-234$ & ICP-MS & $2.56 \mathrm{E}-02$ & $4.09 \mathrm{E}-04$ & $7.9 \%$ & 3 \\
\hline $\mathrm{U}-235$ & ICP-MS & $3.00 \mathrm{E}-04$ & $1.39 \mathrm{E}-02$ & $3.9 \%$ & 3 \\
\hline $\mathrm{U}-236$ & ICP-MS & $2.88 \mathrm{E}-04$ & $4.45 \mathrm{E}-04$ & $8.0 \%$ & 3 \\
\hline $\mathrm{Np}-237$ & ICP-MS & $1.51 \mathrm{E}-02$ & $2.14 \mathrm{E}-03$ & $9.2 \%$ & 3 \\
\hline $\mathrm{U}-238$ & ICP-MS & $6.37 \mathrm{E}-03$ & $1.90 \mathrm{E}+00$ & $2.6 \%$ & 3 \\
\hline $\mathrm{Pu}-238$ & PuTTA & $3.19 \mathrm{E}+01$ & $1.86 \mathrm{E}-04$ & $13.8 \%$ & 3 \\
\hline $\mathrm{Pu}-239 / 240$ & PuTTA & $3.25 \mathrm{E}+00$ & -- & $5.6 \%$ & 3 \\
\hline $\mathrm{Pu}-239$ & ICP-MS & $2.49 \mathrm{E}+00$ & $4.01 \mathrm{E}-03$ & $2.1 \%$ & 3 \\
\hline $\mathrm{Pu}-240$ & ICP-MS & $5.48 \mathrm{E}-01$ & $2.40 \mathrm{E}-04$ & $10.2 \%$ & 3 \\
\hline $\mathrm{Am}-241$ & Cs-r $\gamma$ & $2.16 \mathrm{E}+00$ & $6.30 \mathrm{E}-05$ & $13.7 \%$ & 3 \\
\hline & & & & &
\end{tabular}

The analysis of the free liquid in the original sample and the liquid resulting from water leaching of the solids revealed that the liquid component of the sludge heel has a low salt content. The leached sample material appeared to be consistent with water dilution of the sludge interstitial liquid. Thus, the results for the free liquid and the sample leachate were combined. The liquid portion of the Tank $12 \mathrm{H}$ scrape sample was roughly $\mathrm{pH}=10.0$ to 10.5 with an approximate anion content of carbonate $=6500 \mathrm{mg} / \mathrm{L}$, nitrite $=1600 \mathrm{mg} / \mathrm{L}$, nitrate $=400 \mathrm{mg} / \mathrm{L}$, and other anions $<300 \mathrm{mg} / \mathrm{L}$. 


\subsection{Chemical Cleaning Dip Samples}

\subsection{Samples}

The Tank 12H BOA Cleaning campaign was executed in June and July of 2013. Details on tank conditions and process timing are contained in the completion report. ${ }^{4}$ Table 3-1 lists the samples received by SRNL, the approximate date and time the sample was taken, the day the sample was received by SRNL, a description of the processing stage when sampling occurred, the mass of material received, and the visual assessment of the sample appearance. As planned, SRR sampled near the surface of the liquid at the end of each strike and sent one sample each to SRNL and $\mathrm{F} / \mathrm{H} \mathrm{Lab}{ }^{6}$ Because unplanned additional samples were collected for $\mathrm{F} / \mathrm{H} \mathrm{Lab}$ analysis of $\mathrm{pH}$ at intermediate points during strike 1 and post-strike 3, sampling protocols included pulling additional samples for SRNL as well. Thus, five additional samples were received in addition to the three samples expected.

Table 3-1. BOA Cleaning Dip Samples

\begin{tabular}{c|c|c|c|c|c}
\hline Sample Name & Date/Time & Receipt Date & Description & Sample Weight & Sample Appearance \\
\hline HTF-12-13-93* & $6 / 17 / 201317: 00$ & $6 / 24 / 2013$ & Strike 1 & $89.9 \mathrm{~g}$ & slightly hazy \\
HTF-12-13-96 & $6 / 18 / 201316: 00$ & $6 / 24 / 2013$ & Strike 1 & $71.4 \mathrm{~g}$ & slightly hazy \\
HTF-12-13-98 & $6 / 19 / 20136: 30$ & $6 / 24 / 2013$ & Strike 1 & $73.4 \mathrm{~g}$ & very hazy, light brown \\
HTF-12-13-100 & $6 / 19 / 201316: 30$ & $6 / 24 / 2013$ & Strike 1 & $73.9 \mathrm{~g}$ & hazy, light gray \\
HTF-12-13-102 & $6 / 20 / 201315: 00$ & $6 / 21 / 2013$ & Strike 1 End & $134.2 \mathrm{~g}$ & very hazy, light gray \\
HTF-12-13-116 & $7 / 1 / 201316: 00$ & $7 / 3 / 2013$ & Strike 2 End & $70.7 \mathrm{~g}$ & very hazy, light gray \\
HTF-12-13-127 & $7 / 16 / 20135: 30$ & $7 / 16 / 2013$ & Strike 3 End & $61.9 \mathrm{~g}$ & hazy, light gray \\
HTF-12-13-133 & $7 / 26 / 20139: 30$ & $7 / 29 / 2013$ & Post Strike 3 & $83.6 \mathrm{~g}$ & slightly hazy \\
\hline
\end{tabular}

* sample vial was etched HTF-12-13-93, but accompanying paperwork indicated HTF-12-13-94

Analysis was performed on filtrate from three end of strike samples (HTF-12-13-102, 116, and 127) and two of the intermediate samples from the first strike (HTF-12-13-93, 100). Figure 3-1 contains photographs of the eight dip samples. Portions of the end of strike samples were utilized prior to the photograph being taken, so the volume does not represent the received volume in those cases. Based on the photographs, all samples exhibited some level of haziness, which indicates the presence of insoluble solids. 


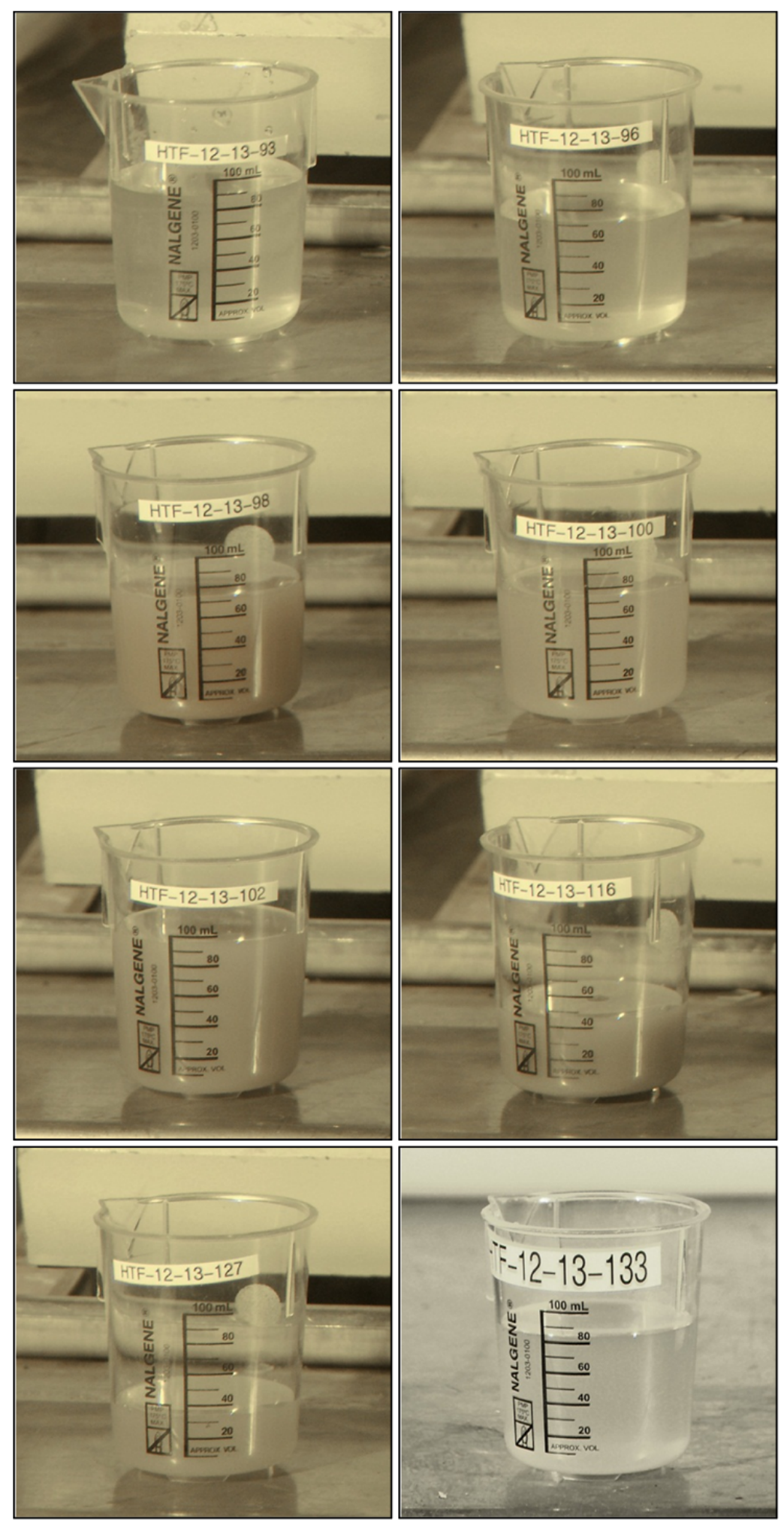

Figure 3-1. Tank 12H BOA Cleaning Dip Samples 


\subsection{Experimental}

SRNL characterized the liquid potion of dip samples from Tank $12 \mathrm{H}$ in support of the BOA cleaning evolution. Additional soluble chemical and radiological components of the BOA cleaning process samples were obtained from a separate dip sample analyzed by $\mathrm{F}$ and $\mathrm{H}$ Area Laboratories $(\mathrm{F} / \mathrm{H} \mathrm{Lab}){ }^{4}$ SRNL analyzed the dip samples for the components outlined in Table 3-2.

The dip samples contained insoluble solids, but the solids were not used in the measurements other than quantifying the total and insoluble solids. For all other analyses, samples were passed through a 0.45 micron nylon filter and the filtrate was used for analysis.

Shortly after sample receipt, filtrate was analyzed in the shielded cells for $\mathrm{Fe}^{2+} / \mathrm{Fe}^{3+}$. Where samples could not be analyzed for $\mathrm{Fe}^{2+} / \mathrm{Fe}^{3+}$ in the same shift as they were received, the samples were removed from the stainless steel receipt bottles and a portion of the sample was filtered and the filtrate stored in a bottle that was covered to prevent exposure of the sample to light. The remainder of the analyses (for Tc-99. I-129, U isotopes, Np-237, Pu isotopes, and Am-241) were performed as a group on all BOA cleaning process end-of-strike samples after the sample from the last (third) strike was received.

Table 3-2. Requested BOA cleaning dip sample SRNL analyses

\begin{tabular}{c|c|c}
\hline analyte & units & measurement method \\
\hline Liquid density & $\mathrm{g} / \mathrm{mL}$ & gravimetric \\
\hline $\begin{array}{c}\text { total solids, soluble solids, } \\
\text { insoluble solids }\end{array}$ & $\mathrm{wt} \%$ & gravimetric drying \\
\hline $\mathrm{Fe}^{2+} / \mathrm{Fe}^{3+}$ (soluble) & ratio & in-cells colorimetric \\
\hline $\mathrm{Tc}-99$ (soluble) & $\mu \mathrm{Ci} / \mathrm{mL}$ & $\mathrm{Tc}-99$ \\
\hline $\mathrm{I}-129$ (soluble) & $\mu \mathrm{Ci} / \mathrm{mL}$ & $\mathrm{I}-129$ \\
\hline $\mathrm{U}-233,234,235,236$, and & $\mu \mathrm{Ci} / \mathrm{mL}$ & ICP-MS \\
\hline 238 & $\mu \mathrm{Ci} / \mathrm{mL}$ & ICP-MS \\
\hline $\mathrm{Np}-237$ (soluble) & $\mu \mathrm{Ci} / \mathrm{mL}$ & Pu-238/Pu-241 \\
\hline $\mathrm{Pu}-238,239 / 240$, and 241 & $\mu \mathrm{Ci} / \mathrm{mL}$ & ICP-MS \\
\hline $\mathrm{Pu}-239$ and 240 & $\mu \mathrm{Ci} / \mathrm{mL}$ & Cs-removed gamma \\
\hline $\mathrm{Am}-241$ (soluble) & &
\end{tabular}

Portions of the as-received and filtered dip samples were dried to a constant weight at $110 \pm 5{ }^{\circ} \mathrm{C}$ to determine total and soluble solids content, respectively. Insoluble solids content of the dip samples were calculated from the total and soluble solids results. 
No target minimum detection limits were specified for the BOA cleaning process dip samples. For most analyses, undiluted samples were removed from the shielded cells and submitted to the various analytical methods.

The quality assurance protocol for the $\mathrm{Fe}^{2+} / \mathrm{Fe}^{3+}$ measurements involved performing additional measurements on Environmental Assessment (EA) glass. ${ }^{7}$ The EA Glass standard has a $\mathrm{Fe}^{2+} / \mathrm{Fe}^{3}$ of 0.22 measured by Corning Labs and of 0.23 measured by SRNL. Historically, $\mathrm{Fe}^{2+} / \mathrm{Fe}^{3+}$ measurements of this material have been in a range of 0.17 to 0.24 .

Additional analytes were measured and reported that are not included in the original request. Among these are additional analytes that were obtained by ICP-MS and Cs-removed gamma. Because it was needed to interpret the $\mathrm{Fe}^{2+} / \mathrm{Fe}^{3+}$ results, samples were analyzed by ICP-ES for iron, which in turn yielded information on many other elemental components.

\subsection{Results and Discussion}

Table 3-3 contains the results of the physical methods performed on the Tank $12 \mathrm{H}$ BOA cleaning samples. Result averages for density and weight percent total and dissolved solids are reported along with standard deviations. Calculated values for weight percent insoluble solids are reported along with a $95 \%$ confidence intervals (C.I.) determined from uncertainty propagation. The samples contained insoluble solids ranging from $0.00 \mathrm{wt} \%$ to $0.34 \mathrm{wt} \%$ (with $95 \%$ confidence intervals typically $0.1 \mathrm{wt} \%$ to $0.2 \mathrm{wt} \%$ ). The slurry densities for the first and second strike samples were typically around $1.012 \mathrm{~g} / \mathrm{mL}$ within experimental uncertainty. Both the density and the weight percent dissolved solids were lower for the third batch samples than for the first and second batch samples.

Table 3-3. Solids and Density Measurements for BOA Cleaning Dip Samples

\begin{tabular}{c|c|c|c|c|c|c|c|c|c|c|}
\hline \multirow{2}{*}{$\begin{array}{c}\text { Sample } \\
\end{array}$} & \multicolumn{3}{|c|}{$\begin{array}{c}\text { Total Solids } \\
\text { (wt\% in slurry) }\end{array}$} & \multicolumn{2}{c|}{$\begin{array}{c}\text { Dissolved Solids } \\
\text { (wt\% in filtrate) }\end{array}$} & \multicolumn{2}{|c|}{$\begin{array}{c}\text { Insoluble Solids } \\
\text { (wt\% in slurry) }\end{array}$} & \multicolumn{2}{c}{ Density (g/mL) } \\
& avg. & st.dev. & n & avg. & st.dev. & n & avg. & 95\% C.I. & avg. & st.dev. \\
\hline HTF-12-13-93 & 1.35 & 0.03 & 3 & 1.35 & 0.08 & 3 & 0.00 & 0.22 & 1.012 & 0.002 \\
HTF-12-13-100 & 1.44 & 0.03 & 3 & 1.36 & 0.06 & 3 & 0.09 & 0.16 & 1.010 & 0.004 \\
HTF-12-13-102 & 1.63 & 0.08 & 4 & 1.51 & 0.09 & 4 & 0.13 & 0.15 & 1.014 & 0.002 \\
HTF-12-13-116 & 1.76 & 0.06 & 3 & 1.43 & 0.07 & 4 & 0.34 & 0.13 & 1.011 & 0.002 \\
HTF-12-13-127 & 0.82 & 0.08 & 4 & 0.76 & 0.06 & 4 & 0.06 & 0.13 & 1.007 & 0.002 \\
\hline
\end{tabular}


Table 3-4. Iron Oxidation State Results for Soluble Portion of BOA Cleaning Samples

\begin{tabular}{c|c|c|c}
\hline \multirow{2}{*}{ Sample Name } & \multicolumn{2}{|c|}{ Sample Analysis } & EA Glass \\
& $\mathrm{Fe}^{2+} / \mathrm{Fe}^{3+}$ & $\mathrm{Fe}^{2+} /$ Total Fe & $\mathrm{Fe}^{2+} / \mathrm{Fe}^{3+}$ \\
\hline HTF-12-13-102 & 0.013 & 0.012 & 0.22 \\
Strike 1 End & 0.020 & 0.019 & 0.22 \\
\hline HTF-12-13-116 & 0.015 & 0.015 & 0.20 \\
Strike 2 End & 0.010 & 0.010 & 0.20 \\
\hline HTF-12-13-127 & 0.009 & 0.009 & 0.21 \\
Strike 3 End & 0.017 & 0.016 & 0.21 \\
\hline
\end{tabular}

Table 3-4 contains the iron oxidation state measurement results for the three end-of-strike samples. For comparison, the results for the quality assurance standard (EA Glass) are also included. For all three end-of-strike samples, $\mathrm{Fe}^{2+}$ content was $2 \%$ or less of the total iron (ranging from $0.9 \%$ to $1.9 \%$ ). The $\mathrm{Fe}^{2+} / \mathrm{Fe}^{3+}$ ratio for EA Glass matched the target value of and the historical range 0.17 to $0.24 \%$

Corrosion of carbon steel in a reducing acid such as oxalic acid can result in the generation of hydrogen gas. However, electrochemical testing demonstrated that reduction of a ferric oxalate species, rather than hydrogen evolution, is the preferred cathodic reaction when dissolved sludge is present. ${ }^{8,9}$ In contrast, in pure oxalic acid, ${ }^{10}$ or after an extended period of stagnant exposure to carbon steel, ${ }^{11,8}$ hydrogen evolution may become the dominant cathodic reaction. The dominance of the hydrogen evolution reaction is presumed to be due to consumption of the ferric oxalate species, which results in an overall decrease in the concentration of ferric ion. Monitoring the total iron and the relative amount of ferric species present throughout the process assists in the assessment of whether there was a significant change in the ferric species.

Table 3-5 indicates that the dissolved iron concentration remained relatively constant for the three strikes ranging between 1100 to $1530 \mathrm{ppm}$. This concentration range is similar to what was observed during the laboratory work. ${ }^{8}$ Likewise the percentage of soluble iron that was ferric ion remained relatively constant, and very high at approximately $98-99 \%$. At these levels of dissolved ferric ion concentrations, ferric oxalate reduction is expected to have been the dominant cathodic reaction throughout the process. Controlling the exposure time of the carbon steel to oxalic acid appears to have reduced the likelihood of ferric ion consumption.

Table 3-5, Table 3-6, Table 3-7 and Table 3-8 contain results for the analysis of the supernatant portion of the dip samples. In most cases, a single aliquot of undiluted sample was sent to the analyst for measurement, and thus no standard deviations are reported for these analytical results. Therefore, the analytical uncertainties should be considered as the nominal uncertainties for the analytical methods, which are $10 \%$ for ICP-ES and $20 \%$ for ICP-MS.

Table 3-5 contains the elemental analysis performed through ICP-ES. Although ICP-ES analysis was not in the original request for the dip sample analysis by SRNL, it was required in order to interpret the iron speciation results. The ICP-ES results reveal that BOA cleaning was effective in dissolving at least a portion of many elemental components of the Tank $12 \mathrm{H}$ heel sludge. The 
dissolved components present at the highest levels in the dip samples are iron, sodium, manganese, uranium, and aluminum.

Table 3-6 and Table 3-7 contain the full fission product and actinide portions of the ICP-MS results. Table 3-8 contains the isotopic results that were measured by ICP-MS or radiochemical counting methods. I-129 and Am-241 were below the method detection limits in the supernatant portions of the dip samples throughout chemical cleaning. Pu-238 was present in the dip sample supernate at up to $0.6 \mu \mathrm{Ci} / \mathrm{mL}$ (at the end of the first strike).

Measurement of strontium-90 and cesium-137 activities was not included in the analysis suite. However, beta/gamma was measured by Liquid Scintillation Counting (LSC) on samples prepared by dilution in nitric acid. This analysis was necessary to facilitate the removal of undiluted samples for the other analyses and the results are reported in Table 3-8. The beta/gamma measurement results can be used as an approximation of the combined activities of Sr-90 and its short-lived decay product Y-90, with a smaller contribution from Cs-137/Ba-137m.

Uranium exhibits a different trend from most of the other elemental and radiochemical analyses. The decrease in uranium concentration between the second and the third strikes is large relative to that for the other analytes. This low soluble uranium concentration in the third strike may indicate the lack of uranium available for dissolution. Thus, the removal of uranium from the Tank $12 \mathrm{H}$ heel may be nearly complete. 
SRNL-STI-2013-00459

Revision 0

Table 3-5. ICP-ES Analysis of Soluble Portion of Tank 12H BOA Cleaning Dip Samples $(\mathrm{mg} / \mathrm{L})$

\begin{tabular}{|c|c|c|c|c|c|}
\hline \multirow{2}{*}{ element } & \multicolumn{3}{|c|}{ Strike 1} & \multirow{2}{*}{$\begin{array}{c}\text { Strike } 2 \\
\text { HTF-12-13-116 }\end{array}$} & \multirow{2}{*}{$\begin{array}{r}\text { Strike } 3 \\
\text { HT F-12-13-12 }\end{array}$} \\
\hline & HTF-12-13-93 & HT F-12-13-100 & HTF-12-13-102 & & \\
\hline $\mathrm{Ag}$ & $<1.06 E+00$ & $<1.06 E+00$ & $<1.06 E+00$ & $<1.06 E+00$ & $<1.06 E+00$ \\
\hline $\mathrm{Al}$ & $84 \mathrm{E}+02$ & $3.13 \mathrm{E}+02$ & $3.32 \mathrm{E}+02$ & $4.24 \mathrm{E}+02$ & $1.92 \mathrm{E}+02$ \\
\hline B & $<1.95 E+00$ & $<1.95 E+00$ & $<1.95 E+00$ & $<1.95 E+00$ & $<1.95 E+00$ \\
\hline $\mathrm{Ba}$ & $1.37 \mathrm{E}+00$ & $1.13 \mathrm{E}+00$ & $2.46 \mathrm{E}+00$ & $3.04 \mathrm{E}+00$ & $2.95 \mathrm{E}+00$ \\
\hline $\mathrm{Be}$ & $<1.00 E-01$ & $<1.00 E-01$ & $<1.00 E-01$ & $<1.00 E-01$ & $<1.00 E-01$ \\
\hline $\mathrm{Ca}$ & $3.95 \mathrm{E}+01$ & $4.07 \mathrm{E}+01$ & $4.85 \mathrm{E}+01$ & $5.29 \mathrm{E}+01$ & $2.24 \mathrm{E}+01$ \\
\hline $\mathrm{Cd}$ & 2.78E-01 & 2.91E-01 & 3.37E-01 & 2.99E-01 & $1.27 \mathrm{E}-01$ \\
\hline $\mathrm{Ce}$ & $<1.00 E+00$ & $<1.00 E+00$ & $<1.00 E+00$ & $<1.00 E+00$ & $<1.00 E+00$ \\
\hline Co & $<2.11 E-01$ & $<2.11 E-01$ & $<2.11 E-01$ & $<2.11 E-01$ & $<2.11 E-01$ \\
\hline $\mathrm{Cr}$ & $7.51 \mathrm{E}+00$ & $7.31 \mathrm{E}+00$ & $6.86 \mathrm{E}+00$ & $8.06 \mathrm{E}+00$ & $2.10 \mathrm{E}+00$ \\
\hline $\mathrm{Cu}$ & $2.51 \mathrm{E}+00$ & $2.66 \mathrm{E}+00$ & $3.61 \mathrm{E}+00$ & $3.70 \mathrm{E}+00$ & $2.75 \mathrm{E}+00$ \\
\hline $\mathrm{Fe}$ & $1.10 \mathrm{E}+03$ & $1.32 \mathrm{E}+03$ & $1.33 \mathrm{E}+03$ & $1.53 \mathrm{E}+03$ & $1.13 \mathrm{E}+03$ \\
\hline $\mathrm{Gd}$ & $<2.35 E+00$ & $<2.35 E+00$ & $<2.35 E+00$ & $<2.35 E+00$ & $<2.35 E+00$ \\
\hline K & $9.80 \mathrm{E}+00$ & $9.23 \mathrm{E}+00$ & $9.59 \mathrm{E}+00$ & $9.83 \mathrm{E}+01$ & $<5.20 E+00$ \\
\hline $\mathrm{La}$ & $<1.42 E+00$ & $<1.42 E+00$ & & $<1.42 E+00$ & $<1.42 E+00$ \\
\hline $\mathrm{Li}$ & $8.31 \mathrm{E}+00$ & $8.77 \mathrm{E}+00$ & $8.66 \mathrm{E}+00$ & $4.13 \mathrm{E}+00$ & $3.74 \mathrm{E}-01$ \\
\hline $\mathrm{Mg}$ & $1.34 \mathrm{E}+01$ & $1.45 \mathrm{E}+01$ & $1.71 \mathrm{E}+01$ & $1.30 \mathrm{E}+01$ & $4.70 \mathrm{E}+00$ \\
\hline $\mathrm{Mn}$ & $7.09 \mathrm{E}+02$ & $7.47 \mathrm{E}+02$ & $8.36 \mathrm{E}+02$ & $8.53 \mathrm{E}+02$ & $2.73 \mathrm{E}+02$ \\
\hline Mo & $<8.30 E-01$ & $<8.30 E-01$ & $<8.30 E-01$ & $<8.30 E-01$ & $<8.30 E-01$ \\
\hline $\mathrm{Na}$ & $1.04 \mathrm{E}+03$ & $1.07 \mathrm{E}+03$ & $1.10 \mathrm{E}+03$ & $6.02 \mathrm{E}+02$ & $3.36 \mathrm{E}+02$ \\
\hline $\mathrm{Ni}$ & $1.23 \mathrm{E}+00$ & $1.24 \mathrm{E}+00$ & $5.42 \mathrm{E}+00$ & $4.89 \mathrm{E}+00$ & $3.90 \mathrm{E}+00$ \\
\hline $\mathrm{P}$ & $1.38 \mathrm{E}+01$ & $1.55 \mathrm{E}+01$ & $1.55 \mathrm{E}+01$ & $1.31 \mathrm{E}+01$ & $5.32 \mathrm{E}+00$ \\
\hline $\mathrm{Pb}$ & $<9.80 E-01$ & $<9.80 E-01$ & $<9.80 E-01$ & & $9.98 \mathrm{E}-01$ \\
\hline $\mathrm{S}$ & & $1.39 \mathrm{E}+02$ & $1.40 \mathrm{E}+02$ & $1.01 \mathrm{E}+02$ & $<8.00 E+01$ \\
\hline $\mathrm{Sb}$ & $<2.90 E+00$ & $<2.90 E+00$ & $<2.90 E+00$ & $<2.90 E+00$ & $<2.90 E+00$ \\
\hline $\mathrm{Si}$ & $1.19 \mathrm{E}+02$ & $1.23 \mathrm{E}+02$ & & $9.36 \mathrm{E}+01$ & $3.02 \mathrm{E}+01$ \\
\hline $\mathrm{Sn}$ & $<1.16 E+00$ & $<1.16 E+00$ & $<1.16 E+00$ & $<1.16 E+00$ & $<1.16 E+00$ \\
\hline $\mathrm{Sr}$ & & $3.87 \mathrm{E}+00$ & & $3.42 \mathrm{E}+00$ & $1.43 \mathrm{E}+00$ \\
\hline Th & $6.04 \mathrm{E}+00$ & $6.63 \mathrm{E}+00$ & $1.15 \mathrm{E}+01$ & $6.78 \mathrm{E}+00$ & $7.31 \mathrm{E}+00$ \\
\hline $\mathrm{Ti}$ & $1.29 \mathrm{E}+00$ & $1.41 \mathrm{E}+00$ & $1.42 \mathrm{E}+00$ & $1.07 \mathrm{E}+00$ & 4.40E-01 \\
\hline $\mathrm{U}$ & $4.99 \mathrm{E}+02$ & $5.18 \mathrm{E}+02$ & $5.42 \mathrm{E}+02$ & $4.07 \mathrm{E}+02$ & $5.84 \mathrm{E}+01$ \\
\hline $\mathrm{V}$ & $<7.10 \mathrm{E}-01$ & $<7.10 E-01$ & $<7.10 E-01$ & $<7.10 E-01$ & $<7.10 E-01$ \\
\hline $\mathrm{Zn}$ & $<1.98 E-01$ & $<1.98 E-01$ & & $5.31 \mathrm{E}-01$ & $4.48 \mathrm{E}-01$ \\
\hline $\mathrm{Zr}$ & $1.61 \mathrm{E}+01$ & $1.75 \mathrm{E}+01$ & $1.79 \mathrm{E}+01$ & $1.40 \mathrm{E}+01$ & $5.35 \mathrm{E}+00$ \\
\hline
\end{tabular}


Table 3-6. ICP-MS Analysis for Fission Products in Soluble Portion of Tank 12H BOA Cleaning Dip Samples (mg/L)

\begin{tabular}{|c|c|c|c|c|c|}
\hline \multirow{2}{*}{$\begin{array}{l}\operatorname{mass} \\
{[\mathrm{m} / \mathrm{z}]}\end{array}$} & \multicolumn{3}{|c|}{ Strike 1} & \multirow{2}{*}{$\begin{array}{c}\text { Strike } 2 \\
\text { HT F-12-13-116 }\end{array}$} & \multirow{2}{*}{$\begin{array}{c}\text { Strike } 3 \\
\text { HTF-12-13-127 }\end{array}$} \\
\hline & HTF-12-13-93 & HTF-12-13-100 & HTF-12-13-102 & & \\
\hline 59 & $<3.50 E-02$ & $<3.50 E-02$ & 7.53E-02 & $1.63 \mathrm{E}-01$ & $1.03 \mathrm{E}-01$ \\
\hline 82 & $<1.36 E+00$ & $<1.36 E+00$ & $<1.36 E+00$ & $<1.36 E+00$ & $<1.36 E+00$ \\
\hline 84 & $<1.75 E-01$ & $<1.75 E-01$ & $<1.75 E-01$ & $<1.75 E-01$ & $<1.75 E-01$ \\
\hline 85 & $2.93 \mathrm{E}-02$ & $1.86 \mathrm{E}-02$ & $<1.50 E-02$ & $<1.50 E-02$ & $<1.50 E-02$ \\
\hline 86 & $<9.00 E-02$ & $<9.00 E-02$ & $<9.00 E-02$ & $<9.00 E-02$ & $<9.00 E-02$ \\
\hline 87 & $6.86 \mathrm{E}-02$ & $8.27 \mathrm{E}-02$ & $7.58 \mathrm{E}-02$ & 5.99E-02 & 2.03E-02 \\
\hline 88 & $2.45 \mathrm{E}+00$ & $2.55 \mathrm{E}+00$ & $2.64 \mathrm{E}+00$ & $2.29 \mathrm{E}+00$ & $1.00 \mathrm{E}+00$ \\
\hline 89 & $<1.00 E-02$ & $1.24 \mathrm{E}-02$ & $9.40 \mathrm{E}-02$ & $6.86 \mathrm{E}-01$ & 4.76E-01 \\
\hline 90 & $3.11 \mathrm{E}+00$ & $3.42 \mathrm{E}+00$ & $3.49 \mathrm{E}+00$ & $2.93 \mathrm{E}+00$ & $1.22 \mathrm{E}+00$ \\
\hline 91 & $2.69 \mathrm{E}+00$ & $3.01 \mathrm{E}+00$ & $3.09 \mathrm{E}+00$ & $2.48 \mathrm{E}+00$ & $9.07 \mathrm{E}-01$ \\
\hline 92 & $3.03 \mathrm{E}+00$ & $3.34 \mathrm{E}+00$ & $3.33 \mathrm{E}+00$ & $2.66 \mathrm{E}+00$ & 9.93E-01 \\
\hline 93 & $4.06 \mathrm{E}+00$ & $4.62 \mathrm{E}+00$ & $4.55 \mathrm{E}+00$ & $3.55 \mathrm{E}+00$ & $1.38 \mathrm{E}+00$ \\
\hline 94 & $3.19 \mathrm{E}+00$ & $3.52 \mathrm{E}+00$ & $3.47 \mathrm{E}+00$ & $2.76 \mathrm{E}+00$ & $1.05 \mathrm{E}+00$ \\
\hline 95 & $1.16 \mathrm{E}-01$ & $1.04 \mathrm{E}-01$ & $9.78 \mathrm{E}-02$ & $1.06 \mathrm{E}-01$ & $5.80 \mathrm{E}-02$ \\
\hline 96 & $3.24 \mathrm{E}+00$ & $3.61 \mathrm{E}+00$ & $3.62 \mathrm{E}+00$ & $3.07 \mathrm{E}+00$ & $1.16 \mathrm{E}+00$ \\
\hline 97 & $4.25 \mathrm{E}-02$ & 4.71E-02 & $5.40 \mathrm{E}-02$ & 4.76E-02 & $1.91 \mathrm{E}-02$ \\
\hline 98 & 5.34E-02 & $6.88 \mathrm{E}-02$ & 7.18E-02 & $8.50 \mathrm{E}-02$ & $3.63 \mathrm{E}-02$ \\
\hline 99 & $2.16 \mathrm{E}-02$ & $2.43 \mathrm{E}-02$ & $1.91 \mathrm{E}-02$ & $1.22 \mathrm{E}-02$ & $<1.00 E-02$ \\
\hline 100 & $1.01 \mathrm{E}-01$ & $1.12 \mathrm{E}-01$ & $1.31 \mathrm{E}-01$ & $9.65 \mathrm{E}-02$ & $3.61 \mathrm{E}-02$ \\
\hline 101 & $2.46 \mathrm{E}+00$ & $2.60 \mathrm{E}+00$ & $2.60 \mathrm{E}+00$ & $2.07 \mathrm{E}+00$ & $1.07 \mathrm{E}+00$ \\
\hline 102 & $2.28 \mathrm{E}+00$ & $2.37 \mathrm{E}+00$ & $2.38 \mathrm{E}+00$ & $1.93 \mathrm{E}+00$ & $9.90 \mathrm{E}-01$ \\
\hline 103 & $1.05 \mathrm{E}+00$ & $1.11 \mathrm{E}+00$ & $1.14 \mathrm{E}+00$ & 7.59E-01 & $2.40 \mathrm{E}-01$ \\
\hline 104 & $1.08 \mathrm{E}+00$ & $1.16 \mathrm{E}+00$ & $1.15 \mathrm{E}+00$ & $9.05 \mathrm{E}-01$ & 4.39E-01 \\
\hline 105 & $<1.50 E-02$ & $<1.50 E-02$ & $<1.50 E-02$ & $<1.50 E-02$ & $<1.50 E-02$ \\
\hline 106 & $<2.50 E-02$ & $<2.50 E-02$ & $<2.50 E-02$ & $<2.50 E-02$ & $<2.50 E-02$ \\
\hline 107 & 2.17E-02 & $1.92 \mathrm{E}-02$ & 7.12E-02 & $3.65 \mathrm{E}-02$ & $2.05 \mathrm{E}-02$ \\
\hline 108 & $1.63 \mathrm{E}-02$ & $1.91 \mathrm{E}-02$ & $1.08 \mathrm{E}-02$ & $1.02 \mathrm{E}-02$ & $<1.00 E-02$ \\
\hline 109 & $<5.50 E-02$ & $<5.50 E-02$ & $<5.50 E-02$ & $<5.50 E-02$ & $<5.50 E-02$ \\
\hline 110 & $3.04 \mathrm{E}-02$ & $3.34 \mathrm{E}-02$ & 4.24E-02 & $3.81 \mathrm{E}-02$ & $1.65 \mathrm{E}-02$ \\
\hline 111 & $3.00 \mathrm{E}-02$ & $3.16 \mathrm{E}-02$ & 3.79E-02 & $3.42 \mathrm{E}-02$ & $1.28 \mathrm{E}-02$ \\
\hline 112 & 8.04E-02 & $6.90 \mathrm{E}-02$ & 8.83E-02 & 6.37E-02 & $1.70 \mathrm{E}-02$ \\
\hline 113 & $<4.10 E-01$ & $<4.10 E-01$ & $<4.10 E-01$ & $<4.10 E-01$ & $<4.10 E-01$ \\
\hline 114 & $6.21 \mathrm{E}-02$ & $5.95 \mathrm{E}-02$ & $6.78 \mathrm{E}-02$ & $6.78 \mathrm{E}-02$ & $<2.00 E-02$ \\
\hline 116 & 7.33E-02 & $8.76 \mathrm{E}-02$ & $1.40 \mathrm{E}-01$ & $8.38 \mathrm{E}-02$ & 8.72E-02 \\
\hline 117 & $1.46 \mathrm{E}-02$ & $2.05 \mathrm{E}-02$ & $1.87 \mathrm{E}-02$ & $1.85 \mathrm{E}-02$ & $1.66 \mathrm{E}-02$ \\
\hline 118 & $6.65 \mathrm{E}-02$ & $5.90 \mathrm{E}-02$ & $5.72 \mathrm{E}-02$ & $5.88 \mathrm{E}-02$ & $3.47 \mathrm{E}-02$ \\
\hline 119 & $2.30 \mathrm{E}+00$ & $2.40 \mathrm{E}+00$ & $2.48 \mathrm{E}+00$ & $1.83 \mathrm{E}+00$ & $3.09 \mathrm{E}-01$ \\
\hline 120 & $5.83 \mathrm{E}-02$ & $5.78 \mathrm{E}-02$ & $6.14 \mathrm{E}-02$ & $5.48 \mathrm{E}-02$ & 4.44E-02 \\
\hline 121 & $1.78 \mathrm{E}-02$ & $2.54 \mathrm{E}-02$ & $2.35 \mathrm{E}-02$ & $<1.50 E-02$ & $<1.50 E-02$ \\
\hline 122 & $2.05 \mathrm{E}-02$ & $1.72 \mathrm{E}-02$ & $1.80 \mathrm{E}-02$ & $1.72 \mathrm{E}-02$ & 1.14E-02 \\
\hline
\end{tabular}

\begin{tabular}{|c|c|c|c|c|c|}
\hline mass & & Strike 1 & & & \\
\hline$[\mathrm{m} / \mathrm{z}]$ & HTF-12-13-93 & HTF-12-13-100 & HTF-12-13-102 & HTF-12-13-116 & HTF-12-13-127 \\
\hline 123 & $1.90 \mathrm{E}-02$ & $2.45 \mathrm{E}-02$ & $2.98 \mathrm{E}-02$ & $1.63 \mathrm{E}-02$ & $<1.00 E-02$ \\
\hline 124 & 2.92E-02 & $2.47 \mathrm{E}-02$ & 3.34E-02 & 2.83E-02 & $2.36 \mathrm{E}-02$ \\
\hline 125 & $2.49 \mathrm{E}-02$ & $2.50 \mathrm{E}-02$ & 3.07E-02 & $2.06 \mathrm{E}-02$ & $<1.00 E-02$ \\
\hline 126 & $6.39 \mathrm{E}-02$ & $6.47 \mathrm{E}-02$ & $7.27 \mathrm{E}-02$ & $5.57 \mathrm{E}-02$ & $2.57 \mathrm{E}-02$ \\
\hline 128 & $2.58 \mathrm{E}-01$ & $2.55 \mathrm{E}-01$ & 2.69E-01 & $<1.85 E-01$ & $<1.85 E-01$ \\
\hline 130 & $1.13 \mathrm{E}+00$ & $1.35 \mathrm{E}+00$ & $1.29 \mathrm{E}+00$ & $9.95 \mathrm{E}-01$ & 3.23E-01 \\
\hline 133 & $1.05 \mathrm{E}-01$ & $1.23 \mathrm{E}-01$ & $1.16 \mathrm{E}-01$ & $7.88 \mathrm{E}-02$ & $2.01 \mathrm{E}-02$ \\
\hline 134 & $<8.00 E-02$ & $<8.00 E-02$ & $<8.00 E-02$ & $<8.00 E-02$ & $<8.00 E-02$ \\
\hline 135 & $3.94 \mathrm{E}-02$ & $2.02 \mathrm{E}-02$ & $3.69 \mathrm{E}-02$ & 4.10E-02 & $2.60 \mathrm{E}-02$ \\
\hline 136 & $<5.50 E-02$ & $<5.50 E-02$ & $<5.50 E-02$ & $<5.50 E-02$ & $<5.50 E-02$ \\
\hline 137 & $2.10 \mathrm{E}-01$ & $1.96 \mathrm{E}-01$ & $3.55 \mathrm{E}-01$ & $3.81 \mathrm{E}-01$ & $3.33 \mathrm{E}-01$ \\
\hline 138 & $1.02 \mathrm{E}+00$ & $8.82 \mathrm{E}-01$ & $1.85 \mathrm{E}+00$ & $2.39 \mathrm{E}+00$ & $2.38 \mathrm{E}+00$ \\
\hline 139 & $<1.00 E-02$ & $<1.00 E-02$ & $4.56 \mathrm{E}-02$ & $6.37 \mathrm{E}-01$ & $6.44 \mathrm{E}-01$ \\
\hline 140 & $<1.00 E-02$ & $<1.00 E-02$ & $3.82 \mathrm{E}-02$ & $5.45 \mathrm{E}-01$ & $3.53 \mathrm{E}-01$ \\
\hline 141 & $<1.00 E-02$ & $<1.00 E-02$ & 4.53E-02 & 5.32E-01 & 4.69E-01 \\
\hline 142 & $<1.00 E-02$ & $<1.00 E-02$ & $3.82 \mathrm{E}-02$ & $5.05 \mathrm{E}-01$ & 3.33E-01 \\
\hline 143 & $<1.00 E-02$ & $<1.00 E-02$ & $4.86 \mathrm{E}-02$ & 5.19E-01 & $4.21 \mathrm{E}-01$ \\
\hline 144 & $<1.00 E-02$ & $<1.00 \mathrm{E}-02$ & $5.53 \mathrm{E}-02$ & 5.61E-01 & $3.53 \mathrm{E}-01$ \\
\hline 145 & $<1.00 E-02$ & $<1.00 \mathrm{E}-02$ & $2.92 \mathrm{E}-02$ & $3.45 \mathrm{E}-01$ & $2.74 \mathrm{E}-01$ \\
\hline 146 & $<1.00 E-02$ & $<1.00 E-02$ & $2.01 \mathrm{E}-02$ & 2.63E-01 & $2.16 \mathrm{E}-01$ \\
\hline 147 & $<1.00 E-02$ & $<1.00 E-02$ & $1.44 \mathrm{E}-02$ & $1.98 \mathrm{E}-01$ & $1.34 \mathrm{E}-01$ \\
\hline 148 & $<1.00 E-02$ & $<1.00 E-02$ & $1.30 \mathrm{E}-02$ & $1.60 \mathrm{E}-01$ & $1.33 \mathrm{E}-01$ \\
\hline 149 & $<1.00 E-02$ & $<1.00 E-02$ & $<1.00 E-02$ & 2.54E-02 & $1.26 \mathrm{E}-02$ \\
\hline 150 & $<1.00 E-02$ & $<1.00 E-02$ & $1.18 \mathrm{E}-02$ & $1.53 \mathrm{E}-01$ & $1.20 \mathrm{E}-01$ \\
\hline 151 & $<1.00 E-02$ & $<1.00 E-02$ & $<1.00 E-02$ & $2.87 \mathrm{E}-02$ & $1.44 \mathrm{E}-02$ \\
\hline 152 & $<1.00 E-02$ & $<1.00 E-02$ & $<1.00 E-02$ & $4.38 \mathrm{E}-02$ & $2.98 \mathrm{E}-02$ \\
\hline 153 & $<1.00 E-02$ & $<1.00 E-02$ & $<1.00 E-02$ & $2.41 \mathrm{E}-02$ & $1.49 \mathrm{E}-02$ \\
\hline 154 & $<1.00 E-02$ & $<1.00 E-02$ & $<1.00 E-02$ & $1.12 \mathrm{E}-02$ & $<1.00 E-02$ \\
\hline 155 & $<1.00 E-02$ & $<1.00 E-02$ & $<1.00 E-02$ & $1.02 \mathrm{E}-02$ & $<1.00 E-02$ \\
\hline 156 & $<1.00 E-02$ & $<1.00 E-02$ & $<1.00 E-02$ & $1.08 \mathrm{E}-02$ & $<1.00 E-02$ \\
\hline 180 & $1.01 \mathrm{E}-02$ & $<1.00 E-02$ & $<1.00 E-02$ & $<1.00 E-02$ & $<1.00 \mathrm{E}-02$ \\
\hline 181 & $1.25 \mathrm{E}-01$ & $1.32 \mathrm{E}-01$ & $1.40 \mathrm{E}-01$ & $1.05 \mathrm{E}-01$ & $5.18 \mathrm{E}-02$ \\
\hline 182 & $1.29 \mathrm{E}-01$ & $3.02 \mathrm{E}-02$ & $2.59 \mathrm{E}-02$ & $2.46 \mathrm{E}-02$ & $<1.50 E-02$ \\
\hline 183 & 7.81E-02 & $1.77 \mathrm{E}-02$ & $1.48 \mathrm{E}-02$ & $1.20 \mathrm{E}-02$ & $<1.00 E-02$ \\
\hline 184 & $1.54 \mathrm{E}-01$ & $4.30 \mathrm{E}-02$ & $4.28 \mathrm{E}-02$ & $3.55 \mathrm{E}-02$ & $<1.50 E-02$ \\
\hline 185 & $<1.00 E-02$ & $<1.00 E-02$ & $<1.00 E-02$ & $<1.00 E-02$ & $<1.00 E-02$ \\
\hline 186 & 1.49E-01 & $3.27 \mathrm{E}-02$ & $3.04 \mathrm{E}-02$ & 2.93E-02 & $1.09 \mathrm{E}-02$ \\
\hline 206 & $1.43 \mathrm{E}-01$ & $1.50 \mathrm{E}-01$ & $1.31 \mathrm{E}-01$ & $2.52 \mathrm{E}-01$ & $1.72 \mathrm{E}-01$ \\
\hline 207 & $1.21 \mathrm{E}-01$ & $1.23 \mathrm{E}-01$ & $1.15 \mathrm{E}-01$ & $1.98 \mathrm{E}-01$ & $1.47 \mathrm{E}-01$ \\
\hline 208 & $2.75 \mathrm{E}-01$ & $2.76 \mathrm{E}-01$ & $2.66 \mathrm{E}-01$ & $5.04 \mathrm{E}-01$ & $3.27 \mathrm{E}-01$ \\
\hline
\end{tabular}


Table 3-7. ICP-MS Analysis for Actinides in Soluble Portion of Tank 12H BOA Cleaning Dip Samples (mg/L)

\begin{tabular}{|c|c|c|c|c|c|}
\hline \multirow{2}{*}{$\begin{array}{l}\operatorname{mass} \\
{[\mathrm{m} / \mathrm{z}]}\end{array}$} & \multicolumn{3}{|c|}{ Strike 1} & \multirow{2}{*}{$\begin{array}{c}\text { Strike 2 } \\
\text { HTF-12-13-116 }\end{array}$} & \multirow{2}{*}{$\begin{array}{c}\text { Strike } 3 \\
\text { HTF-12-13-127 }\end{array}$} \\
\hline & HTF-12-13-93 & HTF-12-13-100 & HTF-12-13-102 & & \\
\hline 230 & $<1.00 E-02$ & $<1.00 E-02$ & $<1.00 E-02$ & $<1.00 E-02$ & $<1.00 E-02$ \\
\hline 232 & $3.88 \mathrm{E}+00$ & $4.66 \mathrm{E}+00$ & $9.57 \mathrm{E}+00$ & $4.84 \mathrm{E}+00$ & $7.03 E+00$ \\
\hline 233 & $5.19 \mathrm{E}-02$ & $7.50 \mathrm{E}-02$ & $6.28 \mathrm{E}-02$ & $5.43 \mathrm{E}-02$ & $1.00 \mathrm{E}-02$ \\
\hline 234 & 8.34E-02 & 8.64E-02 & 8.07E-02 & $5.58 \mathrm{E}-02$ & $<1.00 E-02$ \\
\hline 235 & $3.67 \mathrm{E}+00$ & $4.16 \mathrm{E}+00$ & $3.72 \mathrm{E}+00$ & $2.67 \mathrm{E}+00$ & $4.50 \mathrm{E}-01$ \\
\hline 236 & $1.01 \mathrm{E}-01$ & $1.29 \mathrm{E}-01$ & $1.30 \mathrm{E}-01$ & $6.95 \mathrm{E}-02$ & $<1.00 E-02$ \\
\hline 237 & $3.36 \mathrm{E}-01$ & 3.33E-01 & 3.29E-01 & $2.54 \mathrm{E}-01$ & 8.39E-02 \\
\hline 238 & $4.69 \mathrm{E}+02$ & $4.91 \mathrm{E}+02$ & $4.93 \mathrm{E}+02$ & $3.61 \mathrm{E}+02$ & $5.91 \mathrm{E}+01$ \\
\hline 239 & 3.94E-01 & 4.96E-01 & $5.07 \mathrm{E}-01$ & 3.83E-01 & $1.13 \mathrm{E}-01$ \\
\hline 240 & $2.86 \mathrm{E}-02$ & 4.73E-02 & $3.85 \mathrm{E}-02$ & 2.04E-02 & $<1.00 E-02$ \\
\hline 241 & $<1.00 E-02$ & $<1.00 E-02$ & $<1.00 E-02$ & $<1.00 E-02$ & $<1.00 E-02$ \\
\hline 242 & $<1.00 E-02$ & $<1.00 E-02$ & $<1.00 E-02$ & $<1.00 E-02$ & $<1.00 E-02$ \\
\hline 243 & $<1.00 E-02$ & $<1.00 E-02$ & $<1.00 E-02$ & $<1.00 E-02$ & $<1.00 E-02$ \\
\hline 244 & $<1.00 E-02$ & $<1.00 E-02$ & $<1.00 E-02$ & $<1.00 E-02$ & $<1.00 E-02$ \\
\hline
\end{tabular}


SRNL-STI-2013-00459

Revision 0

Table 3-8. Radionuclides Analyzed in Tank 12H BOA Cleaning Dip Samples $(\mu \mathrm{Ci} / \mathbf{m L})$

\begin{tabular}{|c|c|c|c|c|c|c|}
\hline \multirow[b]{2}{*}{ analyte } & \multirow[b]{2}{*}{ method } & \multicolumn{3}{|c|}{ Strike 1} & \multirow{2}{*}{$\begin{array}{c}\text { Strike 2 } \\
\text { HTF-12-13-116 }\end{array}$} & \multirow{2}{*}{$\begin{array}{c}\text { Strike 3 } \\
\text { HTF-12-13-127 }\end{array}$} \\
\hline & & HTF-12-13-93 & HTF-12-13-100 & HTF-12-13-102 & & \\
\hline Co-60 & & -- & -- & -- & -- & $8.56 \mathrm{E}-05$ \\
\hline Tc-99 & Tc-99 & $2.02 \mathrm{E}-04$ & $2.23 \mathrm{E}-04$ & $2.59 \mathrm{E}-04$ & $1.25 \mathrm{E}-04$ & $<1.79 E-05$ \\
\hline Tc-99 & ICP-MS & $3.67 \mathrm{E}-04$ & 4.11E-04 & $3.24 \mathrm{E}-04$ & 2.07E-04 & $<1.70 E-04$ \\
\hline I-129 & I-129 & $<1.09 E-04$ & $<1.03 E-04$ & $<4.91 E-05$ & $<3.87 E-05$ & $<2.64 E-05$ \\
\hline Eu-154 & & -- & -- & -- & & $2.72 \mathrm{E}-03$ \\
\hline Th-232 & ICP-MS & $4.25 \mathrm{E}-07$ & $5.12 \mathrm{E}-07$ & $1.05 \mathrm{E}-06$ & & $7.71 \mathrm{E}-07$ \\
\hline $\mathrm{U}-233$ & & & $7.26 \mathrm{E}-04$ & & $5.26 \mathrm{E}-04$ & $9.71 \mathrm{E}-05$ \\
\hline U-234 & ICP-MS & $5.21 \mathrm{E}-04$ & $5.40 \mathrm{E}-04$ & $5.04 \mathrm{E}-04$ & $3.49 \mathrm{E}-04$ & $<6.25 E-05$ \\
\hline U-235 & ICP-MS & 7.94E-06 & 8.99E-06 & $8.04 \mathrm{E}-06$ & 5.77E-06 & $9.73 \mathrm{E}-07$ \\
\hline U-236 & ICP-MS & $6.54 \mathrm{E}-06$ & $8.37 \mathrm{E}-06$ & $8.38 \mathrm{E}-06$ & $4.50 \mathrm{E}-06$ & $<6.47 E-07$ \\
\hline U-238 & ICP-MS & $1.58 \mathrm{E}-04$ & $1.65 \mathrm{E}-04$ & $1.66 \mathrm{E}-04$ & $1.21 \mathrm{E}-04$ & $1.99 \mathrm{E}-05$ \\
\hline Np-237 & ICP-MS & $2.37 \mathrm{E}-04$ & $2.35 \mathrm{E}-04$ & $2.32 \mathrm{E}-04$ & $1.79 \mathrm{E}-04$ & $5.92 \mathrm{E}-05$ \\
\hline $\mathrm{Pu}-238$ & & & & & & \\
\hline $\mathrm{Pu}-239 / 240$ & & & & & & $6.94 \mathrm{E}-03$ \\
\hline Pu-239 & ICP-MS & & $3.08 \mathrm{E}-02$ & & $2.38 \mathrm{E}-02$ & $7.01 \mathrm{E}-03$ \\
\hline $\mathrm{Pu}-240$ & ICP-MS & $6.52 \mathrm{E}-03$ & $1.08 \mathrm{E}-02$ & 8.77E-03 & $4.65 \mathrm{E}-03$ & $<2.28 E-03$ \\
\hline $\mathrm{Pu}-241$ & $\mathrm{Pu} 238 / 41$ & $9.59 \mathrm{E}-02$ & $1.22 \mathrm{E}-01$ & $1.42 \mathrm{E}-01$ & $8.24 \mathrm{E}-02$ & $1.94 \mathrm{E}-02$ \\
\hline Am-241 & Cs-r $\gamma$ & $<1.84 E-02$ & $<1.00 E-02$ & $<3.77 E-02$ & $<3.44 E-02$ & $<3.44 E-03$ \\
\hline Beta/Gamma & LSC & $2.58 \mathrm{E}+02$ & $2.91 \mathrm{E}+02$ & $2.94 \mathrm{E}+02$ & $2.39 \mathrm{E}+02$ & $1.01 \mathrm{E}+02$ \\
\hline
\end{tabular}

\subsection{F/H Lab Samples}

For every sample received by SRNL (see Table 3-1) an analogous sample was received by F/H $\mathrm{Lab}$ for analysis. Due to turn-around-time considerations, some analyses were performed at $\mathrm{F} / \mathrm{H}$ $\mathrm{Lab}$ rather than at SRNL. Results for the F/H Lab samples are contained elsewhere. ${ }^{4}$ 
SRNL-STI-2013-00459

Revision 0

\subsection{Material Balance}

\subsection{Process Timeline}

In order to perform a material balance, information about actual processing volumes was used and additional information was provided by email. ${ }^{4,12,13}$

Prior to initiating Strike 1, there was approximately 4406 gallons of sludge heel and the tank liquid level 1.5 inches (4070 gallons).

For Strike 1, 64,551 gallons of $8 \mathrm{wt} \%$ OA were added, followed by approximately 73,400 gallons of well water, bringing the Tank $12 \mathrm{H}$ liquid level to 54.2 inches $(147,000$ gallons). At the conclusion of Strike 1, 115,000 gallons were transferred from Tank $12 \mathrm{H}$ to Tank $51 \mathrm{H}$ bringing the Tank $12 \mathrm{H}$ liquid level to 11.71 inches (31,700 gallons) and leaving an estimated 1263 gallons of sludge heel.

For Strike 2, 18,271 gallons of $8 \mathrm{wt} \%$ OA were added, followed by 46,000 gallons of well water, bringing the Tank $12 \mathrm{H}$ liquid level to 35.43 inches (96,000 gallons). At the conclusion of Strike 2, 70,100 gallons were transferred from Tank 12 to Tank 51 bringing the Tank $12 \mathrm{H}$ liquid level to 9.56 inches (25,900 gallons). For neutralization, 250 gallons of $50 \mathrm{wt} \% \mathrm{NaOH}$ were added, followed by 71,100 gallons of well water, bringing the Tank $12 \mathrm{H}$ liquid level to 35.8 inches (97,000 gallons). At the conclusion of neutralization, 73,004 gallons were transferred Tank $51 \mathrm{H}$ and 867 gallons were transferred Tank $11 \mathrm{H}$, bringing the Tank $12 \mathrm{H}$ liquid level to 9.44 inches $(25,600$ gallons $)$ and leaving an estimated 1225 gallons of sludge heel.

For Strike 3, 23,889 gallons of $8 \mathrm{wt} \%$ OA were added, followed by 46,200 gallons of well water, bringing the Tank $12 \mathrm{H}$ liquid level to 35.29 inches (95,600 gallons). At the conclusion of Strike 3, 71,300 gallons were transferred from Tank $12 \mathrm{H}$ to Tank $51 \mathrm{H}$ bringing the Tank $12 \mathrm{H}$ liquid level to 8.97 inches $(24,300$ gallons). For neutralization, 250 gallons of 50 wt $\% \mathrm{NaOH}$ were added, followed by 69,078 gallons of well water, bringing the Tank $12 \mathrm{H}$ liquid level to 35.2 inches. At the conclusion of neutralization, 52,384 gallons were transferred Tank $51 \mathrm{H}$ and 41,544 gallons were transferred Tank $11 \mathrm{H}$, bringing the Tank $12 \mathrm{H}$ liquid level to 2.0 inches and leaving an estimated 1,000 gallons of sludge heel. ${ }^{14}$

\subsection{Material Balance and Discussion}

In order to perform a material balance, the following assumptions were made. Each assumption limits the applicability of the material balance calculation.

- First, the results for the soluble portions of the dip samples are assumed to be the material removed from the tank. Thus, any suspended insoluble solids that may have been transferred are not included. From the sample analysis information, it is not possible to estimate the removal of insoluble components during BOA cleaning.

- Second, the initial scale sample analysis is assumed to be representative of the entire tank heel. Because the scrape sample was collected from only one area of the tank, we do not have any information on heel material from other areas of the tank. Variations in the tank 
solids heel that are not reflected in the initial scrape sample analysis have not been considered.

Additional uncertainties are introduced by tank volume measurements and the analytical measurement uncertainties. Volatile elements, such as $\mathrm{Hg}$, do not include losses through the tank ventilation system. Sodium is not expected to give a good mass balance for the third strike. The calculation does not include the contribution from sodium contained in the sodium hydroxide added for neutralization after strikes two and three.

A material balance based only on an initial sample of tank heel solids from a single location and samples of solids-free supernatant liquid from the end of each strike requires multiple assumptions to be made that in-turn limit the applicability of the material balance for determining the amount and composition of the solids remaining in the tank. Different assumptions can be made regarding initial composition of heel solids that can influence the material balance. For example, some material balances assume that the solids under the Tank $12 \mathrm{H}$ valve house have a composition more similar to the Tank $12 \mathrm{H}$ bulk sludge removal slurries than that of the initial scrape sample used in this analysis.

Results of the material balance are given in Table 4-1, Table 4-2, and Table 4-3. Masses of soluble constituents removed during each of the three strikes are given in the "Removed" columns and are based on results of the dip sample analyses of Section 3.3 and the process timeline of Section 4.1. In contrast, the total "Original" masses of the constituent are given in the first "Solids" column and are based solely on results of the scrape solids analyses. Estimated percentages of constituents removed through all three strikes are given in the far-right column and are calculated using a combination of the dip sample results and the scrape sample results of Section 2.3. As previously discussed, the removal percentage values should be viewed as order of magnitude estimates, since they are prone to high uncertainties due to expected sample heterogeneities, particularly those of the scrape solids sample. Nevertheless, the removal percentage figures are assumed to provide a reasonable indication of whether large or small portions of each constituent effectively dissolved during the course of the three cleaning strikes.

Based on the results, there appear to be four general categories of constituent removals: 1) those that are high, suggesting near-complete removal; 2) those that are moderate, suggesting significant partial removal; 3) those that are low to borderline moderate, suggesting minor removal; and 4) those that are trivial, suggesting negligible removal. Sodium, potassium, technetium, and phosphorus fall into the first category, with estimated removal values of $90 \%$ and above. Uranium, gross beta/gamma, chromium, iron, magnesium, calcium, zirconium, and silicon fall into the second category, with estimated removal values ranging from 40 to $70 \%$. Plutonium, aluminum, manganese, copper, barium, and lithium fall into the third category, with estimated removal values ranging from 16 to $35 \%$. Mercury, thorium, and nickel fall into the fourth category, with estimated removal values of $6 \%$ or less.

Final characterization of the tank heel during tank closure can be used to support and further understand the material balance for BOA cleaning. The material balance should be reevaluated when additional sample information becomes available. 
Table 4-1. Material Balance for Major Chemical Components

\begin{tabular}{|c|c|c|c|c|c|c|c|}
\hline \multirow{2}{*}{ Analyte } & \multicolumn{4}{|c|}{ Removed (kg) } & \multicolumn{2}{|c|}{ Soldis (kg) } & \multirow{2}{*}{ Removal* } \\
\hline & Strike 1 & Strike 2 & Strike 3 & Total & Original & Remaining & \\
\hline $\mathrm{Al}$ & 145 & 113 & 52 & 309 & 925 & 616 & $33 \%$ \\
\hline $\mathrm{Ba}$ & 1 & 1 & 1 & 3 & 14 & 11 & $19 \%$ \\
\hline $\mathrm{Ca}$ & 21 & 14 & 6 & 41 & 81 & 40 & $51 \%$ \\
\hline $\mathrm{Cr}$ & 3 & 2 & 1 & 6 & 9 & 3 & $64 \%$ \\
\hline $\mathrm{Cu}$ & 2 & 1 & 1 & 3 & 11 & 8 & $29 \%$ \\
\hline $\mathrm{Fe}$ & 580 & 406 & 305 & 1291 & 2704 & 1413 & $48 \%$ \\
\hline $\mathrm{Hg}^{* * *}$ & $<23$ & $<14$ & $<4$ & $<41$ & 641 & $>600$ & $<6 \%$ \\
\hline $\mathrm{K}$ & 4 & 26 & $<1$ & 32 & 12 & -19 & $>100 \%$ \\
\hline $\mathrm{Li}$ & 4 & 1 & 0 & 5 & 30 & 25 & $17 \%$ \\
\hline $\mathrm{Mg}$ & 7 & 3 & 1 & 12 & 23 & 11 & $53 \%$ \\
\hline $\mathrm{Mn}$ & 364 & 226 & 74 & 664 & 2194 & 1530 & $30 \%$ \\
\hline $\mathrm{Na}$ & 479 & 160 & 91 & 730 & 386 & -344 & $>100 \%$ \\
\hline $\mathrm{Ni}$ & 2 & 1 & 1 & 5 & 198 & 193 & $2 \%$ \\
\hline $\mathrm{P}$ & 7 & 3 & 1 & 12 & 13 & 1 & $91 \%$ \\
\hline $\mathrm{S}$ & 61 & 27 & $<22$ & 88 & -- & -- & -- \\
\hline $\mathrm{Si}$ & 58 & 25 & 8 & 91 & 224 & 133 & $41 \%$ \\
\hline $\mathrm{Sr}$ & 2 & 1 & 0 & 3 & 8 & 5 & $36 \%$ \\
\hline $\mathrm{Th}$ & 5 & 2 & 2 & 9 & 166 & 157 & $5 \%$ \\
\hline $\mathrm{U}$ & 236 & 108 & 16 & 360 & 526 & 166 & $68 \%$ \\
\hline $\mathrm{Zr}$ & 8 & 4 & 1 & 13 & 29 & 16 & $44 \%$ \\
\hline Th-232** & 4 & 1 & 2 & 7 & 151 & 143 & $5 \%$ \\
\hline Total U** & 216 & 97 & 16 & 329 & 526 & 197 & $63 \%$ \\
\hline
\end{tabular}

* Removal percentages are reported with greater precision than overall uncertainty warrants

** Dip sample values by ICP-MS *** Dip sample values from F/H-Lab 
Table 4-2. Material Balance for Radionuclides

\begin{tabular}{c|cccc|cc|c}
\hline \multirow{2}{*}{ Analyte } & \multicolumn{4}{|c|}{ Removed (Ci) } & \multicolumn{2}{c|}{ Solids (Ci) } & \multirow{2}{*}{ Re moval* } \\
& Strike 1 & Strike 2 & Strike 3 & Total & Original & Remaining & \\
\hline Tc-99 & 0.113 & 0.033 & 0.005 & 0.151 & 0.079 & 0 & $>100 \%$ \\
Eu-154 & -- & 0.98 & 0.73 & 1.71 & 56.5 & 54.8 & $3 \%$ \\
Np-237 & 0.101 & 0.047 & 0.016 & 0.164 & 0.415 & 0.251 & $40 \%$ \\
Pu-238 & 259 & 87 & 20 & 366 & 877 & 511 & $42 \%$ \\
Pu-239/240 & 18.8 & 8.4 & 1.9 & 29.1 & 89.4 & 60.3 & $33 \%$ \\
Pu-241 & 62.0 & 21.9 & 5.2 & 89.1 & -- & -- & -- \\
$\beta+\gamma$ & $1.28 \mathrm{E}+05$ & $6.34 \mathrm{E}+04$ & $2.73 \mathrm{E}+04$ & $2.19 \mathrm{E}+05$ & $4.84 \mathrm{E}+05$ & $2.65 \mathrm{E}+05$ & $45 \%$ \\
\hline
\end{tabular}

$*$ Removal percentages are reported with greater precision than overall uncertainty warrants

Table 4-3. Material Balanced based on F/H Lab Dip Sample Characterization

\begin{tabular}{c|cccc|cc|c}
\hline \multirow{2}{*}{ Analyte } & \multicolumn{4}{|c|}{ Removed } & \multicolumn{2}{c|}{ Solids } & \multirow{2}{*}{ Re moval* } \\
& Strike 1 & Strike 2 & Strike 3 & Total & Original & Remaining & \\
\hline $\mathrm{Al}(\mathrm{kg})$ & $<29$ & 96 & 56 & 151 & 925 & 774 & $16 \%$ \\
$\mathrm{Fe}(\mathrm{kg})$ & 384 & 358 & 302 & 1045 & 2704 & 1658 & $39 \%$ \\
$\mathrm{Mn}(\mathrm{kg})$ & 342 & 219 & 76 & 637 & 2194 & 1557 & $29 \%$ \\
$\beta+\gamma(\mathrm{Ci})$ & $1.09 \mathrm{E}+05$ & $7.88 \mathrm{E}+05$ & $4.55 \mathrm{E}+03$ & $9.02 \mathrm{E}+05$ & $4.84 \mathrm{E}+05$ & $-4.18 \mathrm{E}+05$ & $>100 \%$ \\
\hline
\end{tabular}

$*$ Removal percentages are reported with greater precision than overall uncertainty warrants

Table 4-4 contains a comparison of the Tank 12H BOA cleaning with previous acidic chemical cleaning results for Tanks $5 \mathrm{~F}$ and $6 \mathrm{~F} .{ }^{15,16}$ Note that for Tanks $5 \mathrm{~F}$ and $6 \mathrm{~F}$, the cleaning process flowsheet differed considerably from that used for Tank $12 \mathrm{H}$. Also the material balances for Tank $5 \mathrm{~F}$ and $6 \mathrm{~F}$ chemical cleaning were established differently than the mass balance for Tank $12 \mathrm{H}$. The material balances for Tanks $5 \mathrm{~F}$ and $6 \mathrm{~F}$ were calculated using a set of dip samples and an end-of-process solids sample, while the material balance for Tank $12 \mathrm{H}$ used analogous dip samples but a pre-cleaning solids sample. Relative to Tank $5 \mathrm{~F}$ and $6 \mathrm{~F}$, the Tank $12 \mathrm{H}$ material balance likely lacks accuracy when solids are nearly completely removed and the method of calculation allows for removal percentages of $>100 \%$.

With a couple of exceptions, the estimated removal percentages for the Tank $12 \mathrm{H}$ samples are on the same order of magnitude as those seen in previous BOA cleaning campaigns. For example, during BOA cleaning of Tank $5 \mathrm{~F}$, a) uranium, aluminum, calcium, and sodium showed high removal; b) zirconium, lithium, manganese, and magnesium showed moderate removal; c) iron, silicon, chromium, and barium showed low removal; and d) nickel showed negligible removal. Although the removal values for Tank $5 \mathrm{~F}$ are not identical to those of Tank $12 \mathrm{H}$, they are reasonably consistent, with exception of those for aluminum. However, given the difference between the PUREX receipts at Tank 5F (low aluminum) and the HM receipts at Tank 12H (high 
aluminum), a clear difference of aluminum chemistry is to be expected. Also, a low temperature aluminum removal campaign had been performed in Tank $12 \mathrm{H}$ prior to BOA cleaning, likely causing the aluminum remaining in the tank heel to be exclusively the more difficult to dissolve boehmite phase. Plutonium and technetium removal were considerably higher in Tank $12 \mathrm{H}$ than for either Tank $5 \mathrm{~F}$ or $6 \mathrm{~F}$; and removal of strontium (as evident through gross beta/gamma removal) was lower in Tank $12 \mathrm{H}$ than in Tanks $5 \mathrm{~F}$ and $6 \mathrm{~F}$. The lower calculated uranium percent removal in Tank $12 \mathrm{H}$ compared with the previous campaigns is likely due to initial heel heterogeneity. The lower levels of soluble uranium in the third strike cleaning solution is consistent with a high degree of uranium removal from Tank $12 \mathrm{H}$.

Table 4-4. Comparison of Calculated Removal Percentages During the Current Tank 12H BOA Cleaning and Previous Tank 5F and 6F Chemical Cleaning

\begin{tabular}{c|ccc}
\hline \multirow{2}{*}{ Analyte } & \multicolumn{3}{|c}{ Mate rial Balance, \% Re moval } \\
& Tank 12H & Tank 5F & Tank 6F \\
\hline $\mathrm{Fe}$ & $48 \%$ & $21 \%$ & $69 \%$ \\
$\mathrm{U}$ & $63 \%-68 \%$ & $89 \%$ & $79 \%$ \\
$\mathrm{Mn}$ & $30 \%$ & $40 \%$ & $47 \%$ \\
$\mathrm{Ni}$ & $2 \%$ & $1 \%$ & $2 \%$ \\
$\mathrm{Na}$ & $>100 \%$ & $88 \%$ & $75 \%$ \\
$\mathrm{Al}$ & $33 \%$ & $81 \%$ & $85 \%$ \\
$\mathrm{Pu}-238$ & $42 \%$ & $5 \%$ & $13 \%$ \\
$\mathrm{Pu}-239 / 240$ & $33 \%$ & $6 \%$ & $14 \%$ \\
$\mathrm{Tc}-99$ & $>100 \%$ & $41 \%$ & $2 \%$ \\
$\beta+\gamma$ & $45 \%$ & $83 \%$ & $87 \%$ \\
$\mathrm{~Np}-237$ & $40 \%$ & $70 \%$ & $73 \%$ \\
$\mathrm{Hg}$ & $<6 \%$ & -- & -- \\
$\mathrm{Ca}$ & $51 \%$ & $92 \%$ & $91 \%$ \\
$\mathrm{Th}$ & $5 \%$ & -- & -- \\
$\mathrm{Si}$ & $41 \%$ & $26 \%$ & $89 \%$ \\
\hline
\end{tabular}

\subsection{Conclusions}

The following are the key observations for Tank 12H Scrape Sample HTF-12-12-107 taken prior to BOA cleaning of the tank heel:

- Iron and manganese were the primary components, followed by aluminum, mercury, uranium, sodium, silicon, nickel and thorium.

- Compared with previous Tank $12 \mathrm{H}$ sludge samples, the scrape sample had a relatively low aluminum:iron ratio of approximately 1:3.

- In terms of activity on a wet basis, the primary radionuclides are strontium-90 at $8.7 \times 10^{3}$ $\mu \mathrm{Ci} / \mathrm{g}$ and cesium-137 at $1.7 \times 10^{2} \mu \mathrm{Ci} / \mathrm{g}$. 
The following are the key observations for the Tank 12H Supernate Samples taken during BOA cleaning. One sample was removed at the end of each BOA cleaning strike. Additionally, two intermediate samples were analyzed for the first BOA cleaning strike.

- The samples contained insoluble solids with a measured range of $0.00 \mathrm{wt} \%$ to $0.34 \mathrm{wt} \%$. Chemical and radiological analyses were performed on solids-free filtrate.

- $\mathrm{Fe}^{2+}$ content was $2 \%$ or less of the total iron (ranging from $0.9 \%$ to $1.9 \%$ ) for each strike.

- Based on the soluble ferric species concentrations at the end of each of the three BOA cleaning strikes, ferric ion reduction was the primary cathodic reaction during chemical cleaning and not hydrogen gas generation. Controlling the exposure time of the carbon steel to the oxalic acid appears to have been effective in mitigating evolution of the flammable gas.

- The major components in the supernate were iron, sodium, manganese, uranium, and aluminum.

- $\mathrm{Pu}-238$ was present in the supernate at up to $0.6 \mu \mathrm{Ci} / \mathrm{mL}$ (at the end of the first strike).

- I-129 and Am-241 were below the method detection limits.

The following are the key observations for the material balance constructed from the Tank $12 \mathrm{H}$ sample data:

- A material balance based only on an initial sample of tank heel solids from a single location and samples of solids-free supernatant liquid from the end of each strike requires multiple assumptions to be made that in-turn limit the applicability of the material balance for determining the amount and composition of the solids remaining in the tank.

- Components that had high, near-complete removal ( $>85 \%)$ include sodium, potassium, and phosphorus.

- Components that had moderate, significant partial removal (40\% to $70 \%)$ include uranium, gross beta/gamma, chromium, iron, magnesium, calcium, zirconium, and silicon.

- Components that had low to borderline moderate, minor removal (15\% to $35 \%)$ include plutonium, aluminum, manganese, copper, barium, and lithium.

- Components that had low, negligible removal $(<6 \%)$ include mercury, thorium, and nickel.

\subsection{Quality Assurance}

Data are recorded in the electronic laboratory notebook system, notebook numbers A6583-00032.

Requirements for performing reviews of technical reports and the extent of review are established in manual E7 2.60. SRNL documents the extent and type of review using the SRNL Technical Report Design Checklist contained in WSRC-IM-2002-00011, Rev. 2.

\subsection{Acknowledgements}

The authors would like to acknowledge the sample preparation by Rita Sullivan, Monica Jenkins, Dee Wheeler, Kevin Reid, and Linda Bush. Sample analysis was overseen by Mark Jones, Boyd Wiedenman, David DiPrete, Ceci DiPrete, Mira Malek, Amy Ekechukwu, and Tom White. 


\subsection{Reference}

${ }^{1}$ H. Colleran and J. Clark, "Tank 12 Bulk Oxalic Acid Cleaning Operating Plan," U-ESH-H00103, Rev. 2, May 2013.

${ }^{2}$ S. Worthy, "Tank 12 Prior to BOAC Solids Sample Analysis," X-TTR-H-00019, Rev. 0, September 2012.

${ }^{3}$ C. J. Martino, S. H. Reboul, and B. J. Wiersma, "Task Technical and Quality Assurance Plan for Tank 12H Chemical Cleaning Sample Analysis," SRNL-RP-2012-00738, Rev. 1, June 17, 2013.

${ }^{4}$ M. D. Buxton, "Tank 12 Acidic Chemical Cleaning Completion Report," SRR-WRC-20130025, Rev. 0, July 2013.

${ }^{5}$ C. J. Martino and W. D. King, "Testing of Enhanced Chemical Cleaning of SRS Actual Waste Tank 5F and Tank 12H Sludges," SRNL-STI-2011-00360, Rev. 0, August 2011.

${ }^{6}$ C. Duffey, "Tank 12 Bulk Oxalic Acid Cleaning Liquid Sample Analysis," X-TTR-H-00020, Rev. 2, June 25, 2013.

${ }^{7}$ C. M. Jantzen, N. E. Bibler, D. C. Beam, C. L. Crawford, and M. A. Pickett, "Characterization of the Defense Waste Processing Facility (DWPF) Environmental Assessment (EA) Glass Standard Reference Material (U),"WSRC-TR-92-346, Rev. 1, June 1, 1993.

${ }^{8}$ B. J. Wiersma, "Treatment Tank Corrosion Studies for the Bulk Oxalic Acid Cleaning Process in H-Tank Farm", SRNL-STI-2012-00305, Rev. 0, May 2012.

${ }^{9}$ B. J. Wiersma, et. al., "Corrosion Testing of Carbon Steel in Oxalic Acid that Contains Dissolved Iron", proceedings of CORROSION 2013, paper no. 2355, NACE International, Houston, TX, 2013.

${ }^{10}$ B. J. Wiersma, "Treatment Tank Off-Gas Testing for the Enhanced Chemical Cleaning Process", SRNL-STI-2011-00444, August 2011.

${ }^{11}$ D. T. Herman, B. J. Wiersma, F. F. Fondeur, J. C. Wittkop, J. M. Pareizs, K. P. Crapse, M. S. Hay, M. R. Poirier, and S.D. Fink, "Investigating Hydrogen Generation and Corrosion in the Treatment Tank and the Potential Formation of a Floating Layer in Neutralization Tank During Waste Tank Heel Chemical Cleaning”, WSRC-STI-2007-00209, April 2007.

${ }^{12}$ C. B. Sherburne, information via email, July 23, 2013.

${ }^{13}$ A. G. Hansen, information from pceweb.srs.gov via email, September 24, 2013.

${ }^{14}$ J. L. Clark, "Tank 12 Preliminary Residual Volume Estimate following BOA Strike 3," U-ESR-H-00109, Rev. 1, September 4, 2013.

${ }^{15}$ M. R. Poirier and S. D. Fink, "Analysis of Samples from Tank 5F Chemical Cleaning," SRNLSTI-2009-00492, Rev. 0, December 9, 2009.

${ }^{16}$ M. R. Poirier and S. D. Fink, "Analysis of Samples from Tank 6F Chemical Cleaning," SRNLSTI-2009-00493, Rev. 0, February 2, 2010. 